\title{
Water Effects of the Use of Western Coal for Electrical Production
}

\author{
E. A. Rogers
}

February 1980

Prepared for the U.S. Department of Energy under Contract EY-76-C-06-1830

Pacific Northwest Laboratory Operated for the U.S. Department of Energy by Battelle Memorial Institute 


\title{
NOTICE
}

\section{$39:$ \\ 17}

This report was prepared as an account of work sponsored by the United States Government. Neither the United States nor the Department of Energy, nor any of their employees, nor any of their contractors, subcontractors, or their employees, makes any warranty, express or implied, or assumes any legal liability or responsibility for the accuracy, completeness or usefulness of any information, apparatus, product or process disclosed, or represents that its use would not infringe privately owned rights.

The views, opinions and conclusions contained in this report are those of the contractor and do not necessarily represent those of the United States Government or the United States Department of Energy.

\author{
PACIFIC NORTHWEST LABORATORY \\ operated by \\ BATTELLE \\ for the \\ UNITED STATES DEPARTMENT OF ENERGY \\ Under Contract EY-76-C-06-1830
}

\author{
Printed in the United States of America \\ Available from \\ National Technical Information Service \\ United States Department of Commerce \\ 5285 Port Royal Road \\ Springfield, Virginia 22151
}

Price: Printed Copy $\$$

$\because$ Microfiche $\$ 3.00$

NTIS

- Pages Selling Price

001-025 $\$ 4.00$

026-050 $\quad \$ 4.50$

$051-075 \quad \$ 5.25$

$076-100 \quad \$ 6.00$

$101-125 \quad \$ 6.50$

$126-150 \quad \$ 7.25$

$151-175 \quad \$ 8.00$

$176-200 \quad 59.00$

$201-225 \quad 59.25$

$226-250 \quad 59.50$

$251-275 \quad 510.75$

$276-300 \quad \$ 11.00$ 


\section{4}

\section{WATER EFFECTS OF THE USE OF WESTERN COAL IOR ELECTRICAL PRODUCTION}

\section{E. A. Rogers}

February 1980

Prepared for the U.S. Department of Energy under Contract EY-76-C-06-1830

Pacific Northwest Laboratory

Richland, Washington 99352 


\section{PREFACE}

This report was prepared as part of the Electric Energy Systems Comparisons and Choices (EES) project, sponsored by the U.S. Department of Energy, Division of Electric Energy Systems and performed by Battelle, Pacific Northwest Laboratory under contract E-76C-06-1830. The objective of this project is to develop an analytical methodology and necessary background information for comparative assessment of salient technical, economic, environmental and resource consumption characteristics of bulk electric energy delivery systems. The assessment methodology is being applied to several hypothetical bulk electric energy systems using Northern Great Plains coal as a primary energy resource. These are sized to deliver $10 \mathrm{GWe}$ (peak) at $90 \% 1$ oad factor to a remote load center. The systems being assessed include:

- Delivery of coal via unit train to steam-electric power plants located at a Midwest load center.

- Delivery of coal via slurry pipeline to steam-electric power plants located at a Midwest load center.

- Mine-mouth gasification of coal and pipeline transmission of gas to combined-cycle power plants located at a Midwest load center.

- Integrated gasifier-combined cycle power plants at the mine-mouth with $D C$ transmission of electricity to a Midwest load center.

- Mine-mouth steam-electric power plants with AC transmission of electricity to a Midwest load center.

- Mine-mouth steam-electric power plants with DC transmission of electricity to a Midwest load center.

- Mine-mouth steam-electric power plants with AC transmission of electricity to a West Coast load center.

The purpose of this report is to assess the water requirements of coalbased electric energy delivery systems in support of the environmental and resource consumption assessments of the Electric Energy Systems project. The 
subject of PNL-3136 was considered to be sufficientiy independent of the remainder of the project to warrant publication as a separate report.

Principle findings of the EES study are being published as a two volume report, as follows.

King, J. C., et al., Electric Energy Supply Systems Comparisons and Choices, PNL-3277, Battelle, Pacific Northwest Laboratory, Richland, WA.

Volume I: Energy Supply System Descriptions

Volume II: Cast Studies 
Water may be a constraint on the expanded development of coal resources in the semi-arid western United States. Water allocation in the West has been determined by the appropriative rights doctrine which allows perpetual use of water sources by those who first claim it for beneficial purposes. This has had the effect of placing a dominate interest in water allocation in one economic sector: agriculture. New water sources are available to coal producers but political and economic problems must be overcome.

Water is required by every phase of coal development. Mines use water for dust control and land reclamation. Coal slurry pipelines would use water as a transport medium. Steam electric power plants use water for cooling, cleaning, and in the boiler. Coal gasification plants would use water for cooling, cleaning, and as a material input. In addition to these direct uses of water by coal development, the people who build and operate the development demand water for domestic and recreational purposes.

The quantity of water required for a given element of a coal development is site specific and dependent on many factors. The available literature cites a range of estimates of the amount of water required for each type of development. The width of this range seems related to the stage of development of the particular technology. Estimates of water requirements for various schemes to provide an average electrical load of 9 GWe to a load center 1000 miles from western mines are shown in Table 5 , page 50. 
. 
PREFACE •

SUMMARY

ACKNOWLEDGMENTS

INTRODUCTION

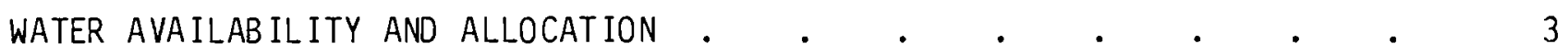

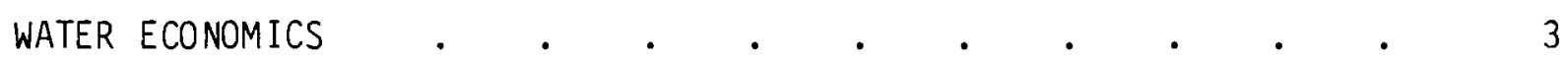

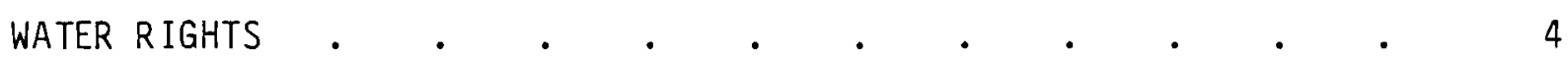

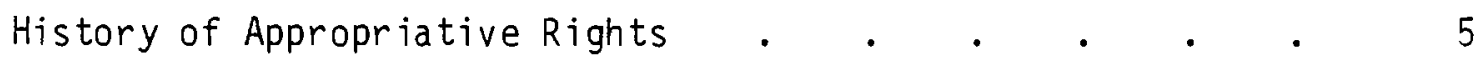

Implications of Appropriative Rights Doctrine

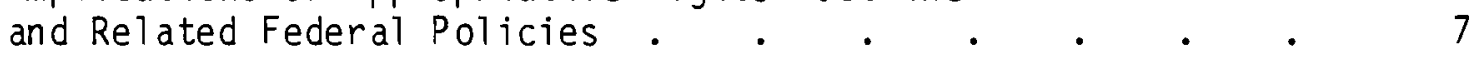

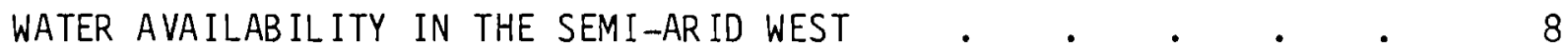

Water Resources of the Northern Great Plains

and Rocky Mountain Regions . . .

Methods of Obtaining Water Available to

Coal Developers

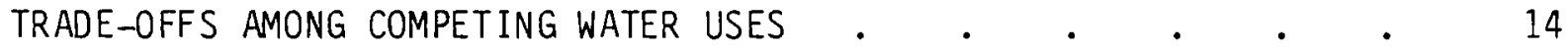

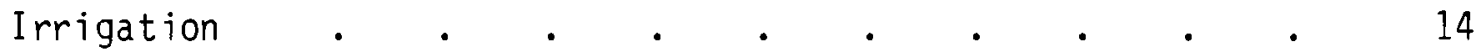

Hydroelectric Power Generation . $\quad$. $\quad$. $\quad$. $\quad$. 14

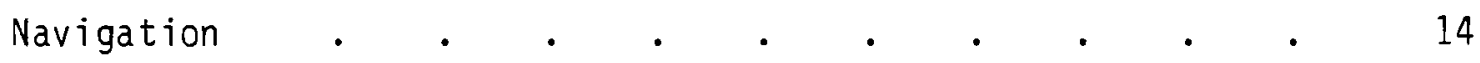

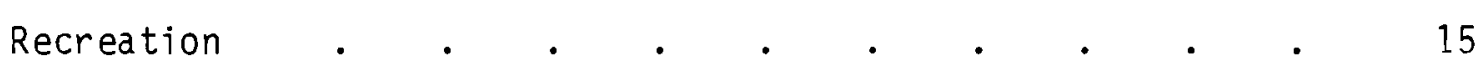

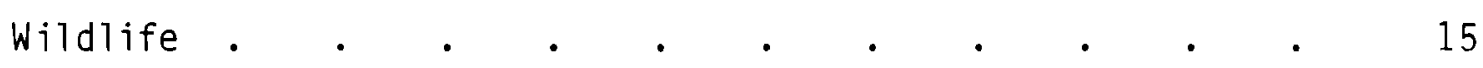

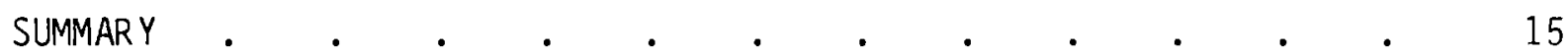

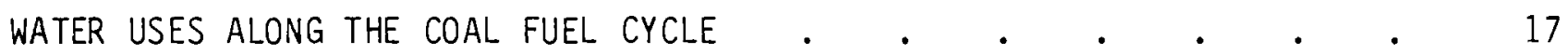

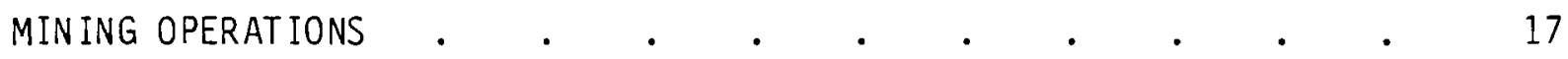

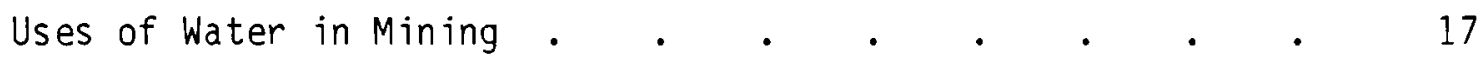

Water Pollution Effects of Mining . $\quad . \quad$. $\quad . \quad$. 20 
Hydrologic Effects of Strip Mining . . . . . . . . $\quad 21$

COAL TRANSPORTATION

Water Effects of Coal Slurry Pipelines . $\quad . \quad$. $\quad . \quad$. 24

ELECTRIC GENERATION •

Uses of Water in Power Plants . . . . . . . . . . . . 28

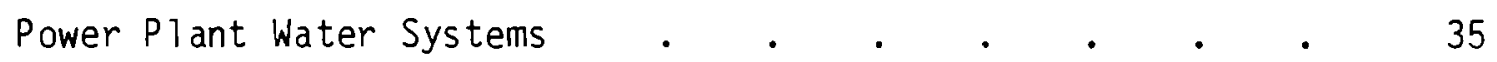

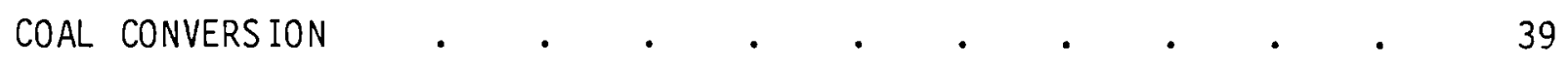

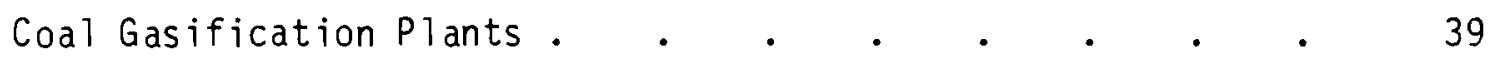

Water Quantity Requirements . . . . . . . . . . 41

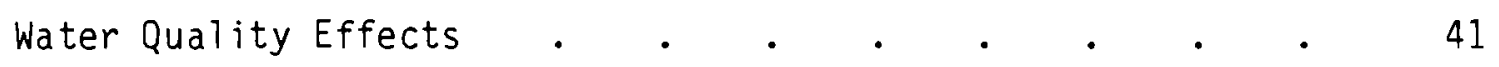

In-Situ Coal Gasification . . . . . . . . . . . 42

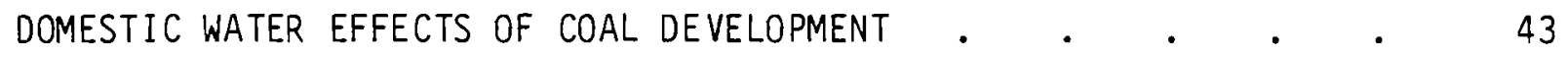

Domestic Water Requirements . $\quad . \quad$. $\quad . \quad$. $\quad . \quad 43$

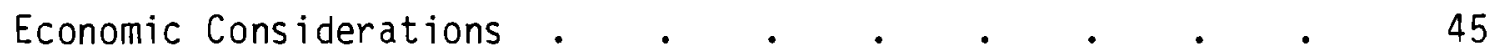

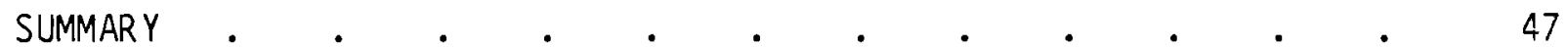

WATER REQUIREMENTS OF A 10 GWe COAL-BASED ELECTRIC

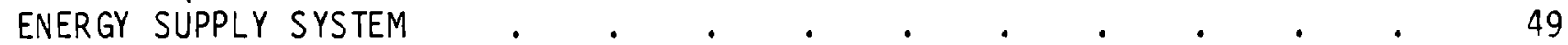

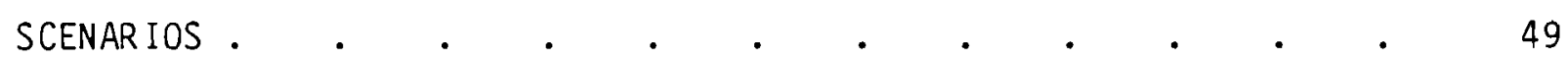

Mine Mouth Steam Generation with AC Transmission Lines . $\quad$ - 49

Mine Mouth Steam Generation with DC Transmission Lines . $\quad 49$

Mine Mouth Gasification and Generation . . . . . . 49

Mine Mouth Gasification with Load Center Generation 51

Load Center Steam Generation with Unit Trains . . 51

Load Center Steam Generation with Slurry Pipelines $\quad$ - $\quad$ • 52

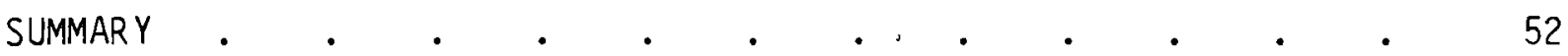

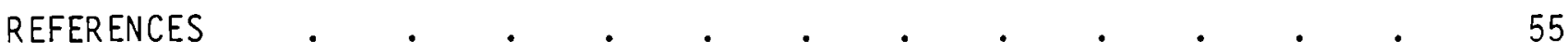




\section{FIGURES}

1 Normal Annual Total Precipitation . . . . . . . . . 9

2 River Systems and Coal Fields of the Semi-Arid West . . . 10

3 Existing and Planned Coal Slurry Pipelines . . . . . . 25

4 Water Systems of a Coal Slurry Pipeline . . . . . . . 26

5 Water Systems of a Hypothetical 1000 MWe Coal-Fired
Power Plant . . . . . . . . . 29

6 Water Systems of a Typical Coal Gasification Process . . . 40

\section{$\underline{\text { TABLES }}$}

1 Water Consumption by Sector in 1975 . $\quad$. $\quad$. $\quad$. $\quad . \quad$. 4

2 Peak Construction Employment of Various Coal Developments . $\quad$ - 44

3 Operational Employment of Various Coal Developments . . . 44

4 Water Requirements for Various Elements of a Coal-Based

5 Estimated Water Requirements for Various 10 GWe Systems . . 50

6 Assumptions for Water Requirement Calculations . . . . . 51 


\section{ACKNOWLED GMENTS}

Several people contributed valuable insights or information which were incorporated into this report. Among these are: John Hertog of the Burlington Northern Railroad, W. R. Keefer of the U.S. Geological Survey, John Phinney of Conoco Coal Development Co., and Robert Swain of the Bureau of Reclamation.

Battelle personnel who contributed include: M. Clement, J. L. Eisenhauer, C. C. Harwe 1, P. L. Hendrickson, J. C. King, E. L. Owzarsk i, R. H. Sauer, G. E. Stegen, and T. L. Whitaker. 

WATER EFFECTS OF THE USE OF WESTERN

COAL FOR ELECTRICAL PRODUCTION

\section{INTRODUCTION}

Of the domestic fossil energy resources available for exploitation, coal offers perhaps the greatest potential for relief from dependence on foreign suppliers of petroleum. Coal development has been constrained in the past by the relative availability and versatility of petroleum and the environmental acceptability of natural gas. Technology exists or will soon be available that will provide coal with the versatility and acceptability of these other energy forms. This technology is quite expensive, but with recent and anticipated price increases of alternate fuels, coal will soon become economically competitive.

One constraint on coal development that cannot be addressed in strictly economic terms is the availability of water. Water is required by every phase of the coal fuel cycle, but much of this nation's coal resources are found in arid and semi-arid regions. Various interests are involved in intense competition for the water that exists in these areas. These interest groups include agriculturalists, municipalities, recreationalists, and environmentalists as well as energy developers.

This report describes the relationship between coal development and water deveiopment. The first section describes constraints on the functioning of a free market economy for water. Among these are institutional constraints of water rights doctrines, and social we lfare constraints of trade-offs between a) ternative water uses. The second section describes the water requirements of various elements of the coal fuel cycle. These include mining, transportation, combustion, and conversion. Water quality aspects are addressed as well as water quantities. The final section estimates the water requirements of an electrical development with a rated capacity of 10 GWe under various generic scenarios. Each scenario provides 9 GWe of average capacity to a load center 
1000 miles away from western coal mines. Western coal was chosen for this analysis because it is more constrained by water availability than is eastern coal. 


\section{WATER AVAILABILITY AND ALLOCATION}

This section on water economics is presented in three parts. The first part explains how water is allocated by the institution of appropriative water rights. The history of water rights doctrine in the West is summarized and contemporary implications of this history are described. Any water allocation scheme functions well until the amount of water demanded exceeds the natural supply. The second part of this section quantifies water availability in the coal regions of the West. Allocating water to one beneficial use of ten precludes using that water for other purposes. The final part of this section describes the trade-offs which must be made when allocating water among competing users.

\section{WATER ECONOMICS}

The value of water is paradoxical. Economic activity cannot take place without it, but it has always been a relatively inexpensive commodity. Now, however, competition between various water users is intensifying in semi-arid regions, and as a consequence, the value of water is beginning to be recognized (National Water Commission 1973). If a perfectly competitive market system existed, the economic value of water would be reflected in its price. Water would be optimally allocated because each sector of the economy would buy and consume water such that the values of marginal products due to water of each sector were equal. If the values of marginal products were found not to be equal, one or more of the sectors would be willing to pay more for their water. The price would rise as sellers of water would try to maximize their own profits.

Discussion of a perfectly competitive market economy for water is academic because there exist within our society institutional, social, and environmental barriers to its functioning. High-value uses, such as domestic water consumption, are supplied through a quasi-market system; there will always be people willing to pay for water used for cooking, bathing, and drinking. But domestic use is only a small fraction of total water demand. As shown in Table 1, most 
water is consumed by low-value uses such as agriculture, industry, and utilities. The table does not reflect water consumed by evaporation from reservoirs built to provide water to the various sectors. Water in these low-value uses is on $1 y$ one input among many required to make a final product. Thus the value of water is determined by its contribution to the production processes rather than by its direct value to consumers. The National Water Commission has observed that in almost every process, there is a way of accomplishing the same objective with less water, but at a higher cost.

\section{WATER RIGHTS}

Two basic systems of water rights allocation are employed in the United States. Eastern states typically have riparian water rights adopted from English common 1aw. Riparian rights allow a landowner to use reasonable amounts of water flowing in a stream through or adjacent to his property. This doctrine precludes use of surface water on tracts of 1 and remote from streams or lakes. Western states typically have appropriative water rights.

TABLE 1. Water Consumption by Sector in 1975 (thousands of acre-ft)

\begin{tabular}{|c|c|c|c|c|c|}
\hline Region & Agriculture & $\begin{array}{l}\text { Municipal } \\
\text { Supply } \\
\end{array}$ & $\begin{array}{c}\text { Industry \& } \\
\text { Mining } \\
\end{array}$ & $\begin{array}{l}\text { Steam } \\
\text { Electric } \\
\end{array}$ & $\begin{array}{c}\text { Total } \\
\text { Consumption }\end{array}$ \\
\hline $\begin{array}{l}\text { Missouri } \\
\text { Basin }\end{array}$ & 18,616 & 549 & 274 & 76 & 19,515 \\
\hline $\begin{array}{l}\text { Upper } \\
\text { Colorado }\end{array}$ & 2,749 & 147 & 55 & 48 & 2,999 \\
\hline $\begin{array}{l}\text { Souris-Red- } \\
\text { Rainy }\end{array}$ & 82 & 36 & 18 & 1 & 137 \\
\hline $\begin{array}{l}\text { Conterminous } \\
\text { United States }\end{array}$ & 111,068 & 9,505 & 9,107 & 1,613 & 131,293 \\
\hline
\end{tabular}

Source: EPA - U.S. Water Resources Council. 
The basic premise of this system is "first in time, first in right." Whoever endeavors to divert the water of a stream first may do so in perpetuity, so long as it is used for "beneficial" purposes. Western Indian reservations have water rights systems with qualities of both riparian and appropriative systems. Unfortunately, these rights have yet to be fully quantified. Until this issue is settled, uncertainty over water allocation throughout the West wi 11 remain.

History of Appropriative Rights

Appropriative water rights originated during the California Gold Rush (Wiel 1908). The early miners had no concept of established law as most were uneducated and many were illiterate. They had nothing to rely on except the customs which they established and their rough-and-ready means of enforcenent. The first person to claim a parcel of land for mining was conceded that right. Likewise, the first person to use the waters of a stream was conceded the right to continue to use them, whether water was returned or not. Thus, it seems that the law of appropriative water rights is actually an extension of mining law.

Within a few years of the gold discovery, hundreds of mining districts in California and surrounding territories had independently adopted appropriative rights systems. However, there were still some lawyers and legalistic lawmakers who believed that riparian laws of the East should be applied in the West. In 1855, the California Supreme Court set a precedent establishing the rule of appropriation for the mining industry. The case of Irwin vs. Phillips involved a canal owner who had diverted water from a stream on public land and a miner who had later located downstream. The opinion read in part:

Courts are bound to take notice of the political and social condition of the country which they judicially rule. In this State... a system has been permitted to grow up by the voluntary action and assent of the population... The miner who selects a piece of ground to work, must take it as he finds it... If it is upon a stream, the waters of which have not been taken from their bed, they $c$ an not be taken to $h$ is prejudice; but if they have been al ready diverted, and for as high and legitimate a purpose as the one he seeks to accomplish, he has no right to complain, no right to interfere with the prior occupation of his neighbor, and must abide the disadvantages of his own selection. (Wiel 1908). 
Mining for gold was California's first industry, and it is easy to understand that early laws would tend to favor miners. But questions remained concerning the application of appropriative rights for purposes of farming and other industries. The California Legislature's Indemnity Act of 1855 required miners who entered upon 1 and of an agriculturalist to post a bond for any damages which may be done to the farmer's improvements. Again, it took the courts to clarify the law. In an early test case, Rogers vs. Soggs, the court held:

Such, in general terms, are the rights of the miner; but these rights are subject to limitations and restrictions necessary to prevent an interference with rights of property vested in others, and which are entitled to equal protection with his own. Thus, he has no right to use water to work his mine which has been appropriated to other legitimate purposes. Nor has he a right to dig a ditch to convey water to his mine over 1 and in the possession of another. Nor can he mine land used for a residence and for purposes connected therewith. Or 1 and used for houses, orchards, vineyards, gardens and the like. (Wiel 1908).

And thus the doctrine of appropriative water rights was established in California applying equally to all "legitimate purposes." The criticism has thus been made that the appropriative doctrine was established judicially, independent of legislation.

The California example spread to other emerging western states. A Nevada judge wrote in an early decision:

So $f$ ar, then, as the anomalous rights and character of the miner locating upon the public land, for the purpose of mining, are defined and established by the courts of California, we feel it is our duty to recognize them whenever their decisions may be applicable to our condition. To repudiate the theory and principals upon which they have acted would be to overturn the foundation upon which half our rights rest. (Wiel 1908).

The first Federal law condoning appropriative rights was passed in 1867 and was entitled "An Act Granting the Right-of-Way to Ditch and Canal Owners Through the Public Lands, and for Other Purposes."

One is forced to wonder what the development of the West would have been like were it not for the fortuitous discovery of gold in California. The rush of 1849 created a nation developed on both coasts with large unsettled regions 
between. Before the gold strike, the nation had been slowly expanding westward. New states generally adopted the doctrines of nearby states. The Federal law of 1867 applied only to Federal lands so the established areas in the East were virtually unaffected, but 1 ands in the western territories were almost exclusively owned by the Federal government. Thus, today this nation has a dichotomy of water 1 aws. It may be just as well that appropriative rights were adopted in such a manner as it is not certain that riparian rights would have been conducive to development in the semi-arid West. In the East water is abundant and springs or streams occur on almost every large tract of 1 and. In contrast, the West has vast areas that are without water. The development of these lands would have been impossible if enterprising individuals had not been able to divert and transport what water there was.

Implications of Appropriative Rights Doctrine and Related Federal Policies

The biggest benef actors of the appropriative water rights system were not the miners who originated the scheme but rather the agriculturalists who moved in later. In recent years, up to $83 \%$ of a 11 water consumed in the United States has been used for irrigation (National Water Commission 1973). Irrigation is used most in states that have appropriative water rights. Although the doctrine was not designed specifically with farmers in mind, it fit in well with the prevailing national ethic which held that family farms are inherently good. This ethic had its origins in colonial days and continues today. Thomas Jefferson surmarized this ideal when he wrote, "The small 1 andholders are the chosen people of God .. . whose breasts He has made His pecu$1 i$ ar deposit for substantial and genuine virtue." (Udall 1963). Legislative manifestations of this ethic that have facilitated the agriculturalist's dominance of western water allocation are the Homestead Act of 1862 and the Reclamation Act of 1902.

One valid criticism of the appropriative water rights doctrine is its inflexibility. Priorities of water distribution in the West reflect the priorities of the nineteenth century rather than prevailing priorities. 
WATER AVAILABILITY IN THE SEMI-ARID WEST

As mentioned above, most of the water in the western United States is currently allocated to agriculturalists. Many basins have more water allocated than is available. Because seniority of water rights is determined by the date of the claim rather than by the date water is actually diverted, it has been advantageous to make a claim and defer exercising it indefinitely. Many of these unexercised water claims were made by agriculturalists in anticipation of construction of Federal water projects (Goslin 1975). The Bureau of Reclamation typically designs and oversees construction of these projects and then contracts with local irrigation districts to deliver water at prices below the economic value of the water. The Reclamation Act limits this subsidy to parcels of 1 and of 160 acres or less, but this limitation has been only sporadically enforced. A court has recently ordered the Department of Interior to either enforce this 1 aw or change it by 1980 . Legislation on this matter is currently being debated. The Senate has passed a bill which would raise the 1 imit to 1280 acres and this is now being considered by the House of Representatives.

Water Resources of the Northern Great Plains and Rocky Mountain Regions

Without irrigation, agricultural activities in the semi-arid West would be impossible or greatly curtailed. As shown in Figure 1 , average annual precipitation ranges from 8 to $24 \mathrm{in.}$ and is typically 10 to $16 \mathrm{in.}$ (Packer 1974). Much of this occurs as snowfall during the winter or as intense thunderstorms during the sumer. Farmers would undoubtedly prefer to receive all their mo isture by gentle drizzles during the growing season. Massive irrigation projects reconcile this inconsistency by retaining snowmelt and runoff for gradual use during the growing season.

The two major river systems near the coal fields of the West are the Missouri River in the northern Great Plains and the Colorado River in the Rocky Mountain Region. These river basins are believed to contain over 100 billion tons of strippable coal reserves. This represents $75 \%$ of national strippable coal reserves (Davis and Kilpatrick 1979). The location of these coal reserves and river basins is shown in Figure 2. The waters of each basin are divided 


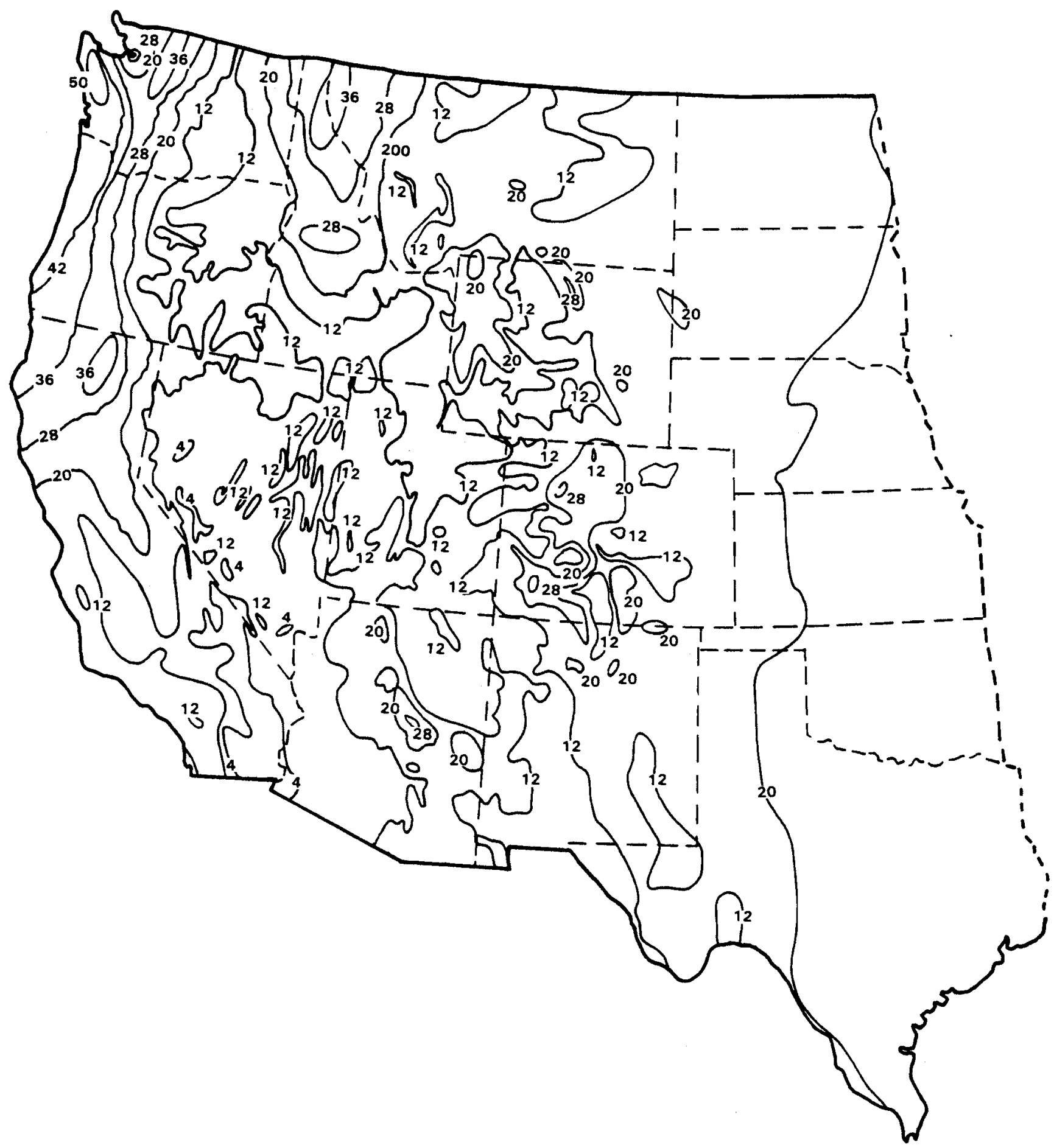

FIGURE 1. Normal Annual Total Precipitation (inches) Source: Climate Atlas of the United States 


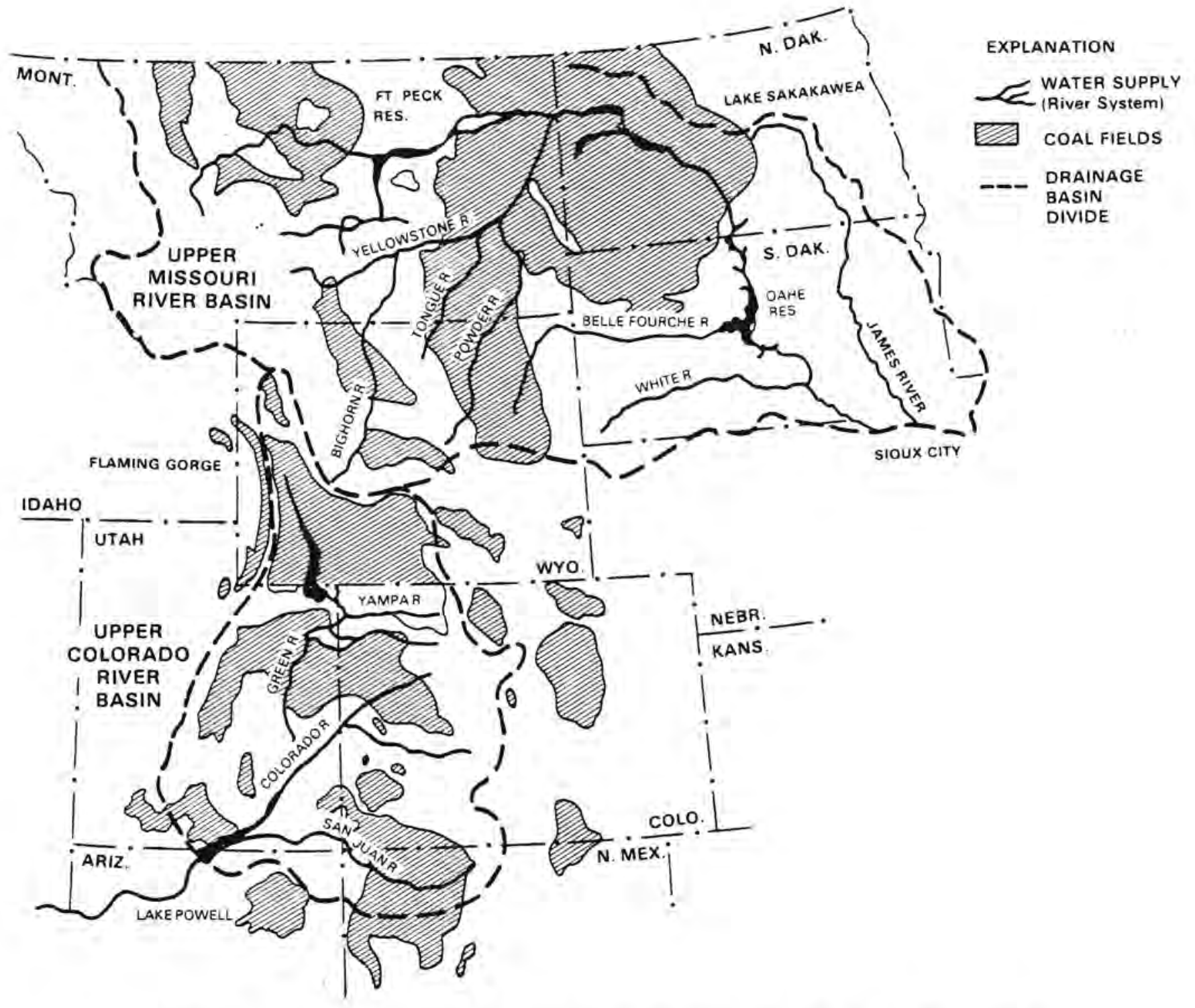

FIGURE 2. River Systems and Coal Fields of the Semi-Arid West Source: Davis and Kilpatrick 1979

among states by various river compacts. The Colorado River Compact assumes that the average annual flow available for use in the upper basin (upstream of Lee Ferry, Arizona) is 7,500,000 acre-ft/yr. Unfortunately, this assumption, made in 1922, was based on inaccurate data, and the actual amount available is now known to be somewhat less. The Bureau of Reclamation uses a figure of $5,800,000$ acre-ft/yr for planning purposes (Goslin 1975). The average annual 
flow of the Missouri River at Oahe Reservoir in South Dakota is about $18,500,000$ acre-ft/yr (BuRec 1977). While this supply is adequate during normal times, local water shortages occur during periods of low flow, especially in parts of the Powder River and Yellowstone River Basins.

The entire region is underlain with both shallow and deep aquifers. Shallow aquifers have been widely exploited by agriculturalists and water tables throughout the region have dropped significantly during this century. Deep aquifers are currently immune to exploitation by agriculturalists due to high pumping costs and poor water quality.

Methods of Obtaining Water Available to Coal Developers

Because many of the basins near western coal fields are already overappropriated, it would be futile for energy developers to attempt to procure water by appropriation, as any water right granted today would be junior to rights granted previously. There are, however, at least five options for obtaining water available to energy developers. These are: exploiting deep aquifers, building aqueducts from the mainstem of the Missouri River, recycling wastewater, purchasing or leasing existing senior water rights, and procuring $a b$ andoned water rights. All of these options are quite expensive.

\section{Deep Aquifers}

Energy Transportation Systems, Inc. (ETSI) has selected a deep aquifer in the Madison Formation as the source of water for their proposed slurry pipeline originating near Gillette, Wyoming. The estimated cost of procuring this water will be about $\$ 130$ per acre-ft while agriculturalists in the area typically pay $\$ 8$ per acre-ft for high quality water from shallow aquifers (1978 dollars; 0dasz 1978). The recharge rate of the Madison Formation is estimated to be around 100,000 acre-ft/yr (BuRec 1977). If withdrawals do not exceed recharge, the water table would remain stable and no water rights would be violated. However, little information is available on the natural fate of water in these deep aquifers. If 100,000 acre-ft of water has percolated into the Madison Formation each year for eons, where has it all gone? Has it just 
accumulated in the aquifer or is it discharged somewhere somehow? Until this is fully understood, the impacts of withdrawal will remain uncertain.

Missouri River

Also considered in the ETSI economic analysis was an aqueduct from 0 ahe Reservoir on the Missouri River to Gillette. The estimated cost of delivered water would be around $\$ 1000$ per acre-ft (1978 dollars; Odasz 1978). The Bureau of Reclamation has also studied the feasibility of constructing large diversion projects from the mainstem of the Missouri River to energy developments. The study concludes that up to $3 \mathrm{milli}$ ion acre-ft/yr of water currently allocated to future agricultural development could be diverted for energy development until it is needed for irrigation. Time-related estimates of the available water are 3 million acre-ft/yr until the year 2000, 2.7 million until 2013, 2.0 million until 2023, and 1.2 million until 2033 (BuRec 1977).

Concern over this hypothetical proposal by BuRec has been expressed by agriculturalists who fear that once the investment is made by energy deve1opers, it will be difficult to revert the allocation to agriculturalists. The Bureau has responded to the farmer's concerns by saying that contracts will be made with specific expiration dates. Near the end of the allocation period, contracts would be renegotiated to reflect the needs and desires of the Nation at that time. The complaint of inflexibility by the irrigators would seem to be counter-productive to their own cause as it highlights the fact that existing appropriative rights laws are quite inflexible with respect to allocating water to current national priorities.

Recycling Wastewater

Another potential source of water to energy developers is secondary effluent from municipal sewage treatment plants. This source could be attractive for water uses which do not require high water quality such as power plant cooling, or slurry pipelines. The cost of treating and transporting waste water 25 miles in California has been estimated to be about $\$ 360$ per acre-ft (1977 dollars; Hendrickson 1978). However, this source is only viable for energy developments located near large metropolitan areas. 


\section{Lease of Water Rights}

The largest potential source of water for energy developers is existing water rights. Many unexercised rights will never be economic to develop. Because the discount rate used for the economic analyses of Federal water projects has recently been raised to $7-1 / 8 \%$, many proposed and authorized water projects are no longer economically feasible. Owners of unexercised rights may soon realize that they possess a valuable commodity. If a competitive market for water rights could be established, the economic value of water would finally be recognized. Even agriculturalists currently exercising water rights could optimize their returns by contracting with energy producers to provide water during droughts. During plentiful years, the requirements of the energy industry could be fulfilled with junior rights and farmers with senior rights could tend to their fields. During dry years, irrigators could lease their senior water rights to energy producers and allow their fields to remain fallow. The average crop value from irrigated land in the West is about $\$ 400$ per acre greater than that from nonirrigated 1and, and average water application on irrigated 1 and is $2.4 \mathrm{ft}$ (U.S. Department of Comerce 1978). Therefore, if irrigators could lease their water rights for more than $\$ 200$ per acre-ft, profits from water leases could conceivably exceed those of irrigated farming.

\section{Abandoned Water Rights}

There are legal mechanisms for revoking existing water rights on the grounds that they have been abandoned, but the procedure can be 1 ong and complex. A prospective water user must claim that a specific existing water right has been abandoned, and prove that the owner of the existing water right intended to abandon it. The fact that the water right has not been exercised for an unreasonable period is prima facie evidence that it has been abandoned, but this presumption may be rebutted with other evidence. What constitutes an unreasonable period is typically a judicial opinion, but at least one state, Colorado, has legislated 10 years as the period which constitutes a rebuttable presumption of abandonment. 


\section{TRADE-OFFS AMONG COMPETING WATER USES}

Consuming water for one purpose precludes using that water for other purposes. In order to evaluate the full impact of diverting water to coal development, one must consider the impact on other water uses. In addition to irrigation, water uses which will be impacted by coal development include hydroelectric power generation, river navigation, water recreation, and wildlife.

\section{Irrigation}

Even large-scale energy development will probably not have a major effect on the total number of cultivated acres. A study done on eastern Montana coal fields indicated that, at most, coal development would cause a $1 \%$ decline in agriculture (Polzin 1974). In some areas, it may be possible to divert substantial amounts of water from the agricultural sector to the industrial sector, without reducing irrigated acreage, by improving irrigation efficiency. For example, where flood irrigation can be replaced with sprinkler application, as much as one-third of the water previously required could be diverted to energy development (Hendrickson 1978).

\section{Hydroelectric Power Generation}

The Bureau of Reclamation reports that annual diversion of 1 million acre-ft from Missouri mainstem reservoirs would reduce hydroelectric peaking capacity by eight megawatts $(0.37 \%)$ and an annual power production by $468 \mathrm{mil}$ lion KWh (5.5\%) (BuRec 1977). If this water was diverted to coal gasification facilities, about 6,400 times as much energy could be produced by the gasified coal as could be produced by hydroelectric plants. Water diverted from the Missouri to coal-fired power plants could be used to produce 800 times as much electricity as hydroelectric plants produce (BuRec 1977).

\section{Navigation}

The Corps of Engineers is responsible for operation of mainstem Missouri River dams and for maintenance of navigation channels downstream. During the eight-month navigation season, about 35,000 cubic feet per second (cfs) are required for full service. In the year 2000 , release estimates are 31,900 cfs 
if no water is diverted to energy development and 30,600 cfs if 1 million acre-ft are diverted. The difference would not significantly affect navigation (BuRec 1977)

\section{Recreation}

Most water recreation along the mainstem of the Missouri takes place on the reservoirs. Except during droughts the level of the lakes can be the same regardless of flow rates, so large diversions are not expected to affect this form of recreation. Suppression of flow in free-flowing reaches could, however, adversely affect fishing and boating.

\section{Wildlife}

Aquatic species could be affected by increased diversions from the Missouri mainstem. A diversion of $1 \mathrm{million}$ acre-ft would increase the total dissolved solid concentration of the river by about one or two percent, and this could have an adverse effect on sensitive species (BuRec 1977). Lowered water levels along free-flowing reaches could have adverse effects on aquatic life, especially species living near the shore. Intake structures and other diversion structures could conceivably kill some fish.

\section{SUMMARY}

A current national goal is to achieve energy self-sufficiency. Development of our coal reserves in the semi-arid West is an important step in achieving this goal; such development, however, will require vast quantities of water. Unfortunately, water allocation in the West is currently determined by ni neteenth century priorities. The National Water Commission has observed that under the existing allocation system, economic efficiency cannot be achieved. In order to do so, the value of water must be reflected in its price (National Water Commission 1973).

Farmers in this country pay between $\$ 5$ and $\$ 150$ per acre-ft for irrigation water, but their costs are usually well below $\$ 20$ per acre-ft (Hendrickson 1978). Even with subsidized water, many farmers are finding it difficult to make a profit. Because American farmers currently produce much more food than 
can be consumed (with the surplus often purchased by the Federal government) it is argued that the benefits to the nation of water supply and allocation schemes favoring agriculturalists may not exceed their costs. It must be recognized that situations are different now than when the Jeffersonian ideals of small farming were conceived and when the Reclamation Act was written. The appropriative water rights doctrine was a radical concept when it was formulated in California over a century ago, but it has evolved incrementally. The needs of the nation have now outpaced the evolution of this doctrine and today the economic growth and the security of the nation are inhibited by it.

There is ample water available in the semi-arid West, but it is mostly from unconventional sources and would be quite expensive. However, energy developers are willing to pay orders of magnitude more for water than farmers can afford to pay because the cost of water to energy developers is not a significant factor in the overall development. For example, a USGS study on coal slurry pipelines indicated that in order to economically justify a $10 \%$ water savings over that of the technically optimal design, water would have to cost over $\$ 1000$ per acre-ft (USGS 1977). It has also been observed that the costs of energy developments are much more dependent on interest rates than on water cost (NGPRP 1974).

The economic benefits obtained from energy development far outweigh those of agriculture, when compared on an equal water basis. If economic efficiency is to be achieved, some method must be devised to facilitate transfers of water rights from agriculturalists to energy developers. 


\section{WATER USES ALONG THE COAL FUEL CYCLE}

Construction of mines, power plants, transmission lines, conversion facilities, and pipelines requires some water, but typically much more water is required during the operational phases of coal development. The major uses of water during mining operations are dust control and land reclamation. Coal slurry piplines use water as the transport medium, but other coal transportation options require only minimal quantities of water. Coal-fired power plants are the greatest consumers of water along the fuel cycle. Their water uses include cooling, boiler feed, ash handling, and emission control as well as several miscellaneous uses. Conversion facilities, such as coal gasification plants, use water for cooling, pollution control, and as a source of hydrogen. In addition to water consumption each step of the fuel cycle affects the quality of the water resources.

\section{MINING OPERATIONS}

Water is required for the operation of a coal mine. Mining can also contribute to surface and groundwater pollution and often has a disruptive effect on the localized hydrology. The quantities of water required may vary significantly between surface and deep mines, but many of the uses are the same. However, the pollution and hydrologic effects of the two mining methods may be quite different. Most of the coal development in the West will be surface mines (as least in the near future), as the region has vast quantities of coal near the surface which can be extracted at far lower costs than deep coal. Therefore, this section will emphasize the water effects of surface mining operations.

Uses of Water In Mining

Surface and deep mining operations use water for dust control, machinery maintenance, and coal preparation. Surface mines of ten have the additional water use requirements of 1 and reclamation, especially in arid or semi-arid locations. 


\section{Dust Control}

The 1 argest use of water around a coal mine is for dust control. All mines must control windblown dust from haul roads and other disturbed areas. Underground mines must control dust inside the mines to protect the miners. The amount of water required for dust control depends on the size of the mine, the distance from the mine to the preparation area, and most importantly, the local $\mathrm{climate.} \mathrm{In} \mathrm{areas} \mathrm{of} \mathrm{high} \mathrm{humidity} \mathrm{and} \mathrm{frequent} \mathrm{rainf} \mathrm{all,} \mathrm{disturbed}$ areas revegetate quickly and dust seldom blows. In the West, however, mine areas are typically quite dry and of ten windy so haul roads must be wetted frequently. Estimates of the quantity of water required for dust control around western surface mines range from 5 to $12 \mathrm{gal} /$ ton of coal extracted (Gold, et al. 1977 and WPPSS 1977).

The quality of water used to suppress dust is not important, and water collected from intercepted aquifers is often used. This practice solves two problems, as the collected water is of ten contaminated with sulfur and other mineral compounds and would otherwise have to be treated before discharge.

Machinery Maintenance

Water is used to clean machinery and to cool some machines. The amount of water used for machinery maintenance is negligible compared with other uses, but the pollutants created can be significant. Waste water from equipment maintenance may contain oils, grease, fuels, antifreeze, suspended solids, and detergents.

\section{Coal Preparation}

Coal of ten must be crushed and cleaned before being transported to market. Water is sometimes used to control dust from the crushing process, but more of ten the crushers are enclosed and dust is contained. When water is used in the crushing process, about $5 \mathrm{gal} /$ ton of coal is typically required (Gold et a1. 1977). About $6 \mathrm{gal} /$ ton are consumed by washing (Bhutani 1975). Because western coal is typically from rather thick seams, impurities from the seam edges do not present much of a problem. Therefore, western coal mines seldom need to wash their coal. 


\section{Revegetation}

Water may be required to revegetate stripped 1 ands after the coal has been removed. Irrigation is essential for revegetation in areas where annual precipitation is less than 10 in., and is beneficial in most semi-arid coal fields. While moisture availability is the most important parameter affecting rehabilitation potential, there are several other factors involved. These include the microclimate, availability of suitable plant species, site preparation, planting procedures, fertilizer, soil stability, and post-revegetation care. Because of the many factors involved, the amount of irrigation required for successful revegetation is site-specific. A range of $0.5 \mathrm{acre}-\mathrm{ft} / \mathrm{acre}$ to 4.0 acre-ft/acre has been suggested for semi-arid regions (Western States Water Council 1974). Typically, irrigation would be required only during the first year of revegetation; after the plants become established they can survive on natural precipitation.

The Office of Surface Mining is mandated by the Surface Mining Control and Reclamation Act of 1977 to formulate guidelines and regulations concerning reclamation procedures. These regulations are not yet finalized and thus there is some uncertainty within the coal mining industry over the extent of responsibility of the producers. Due to this uncertainty, estimates of reclamation costs vary widely. For the Appalachian region, cost est imates range from $\$ 300$ per acre (1975 dollars, Mitre 1975) to $\$ 460$ per acre (1968 dollars, Commoner, et a1. 1975). Cost estimates for reclamation of Northern Great Plains coal fields range from $\$ 700$ to $\$ 1000$ per acre (1974 dollars, Packer 1974). Costs for 1 and reclamation in northern Germany are significantly higher than those estimated for this country. Up to $\$ 10,000$ per acre are spent on a carefully controlled process (1968 dollars, Comoner, et al. 1975). Typically, the reclaimed 1 and is ready for cultivation within a year after mining, whereas the practices proposed for this country would require 5 to 15 years before the 1 and could be productive. The German procedure is cost effective only because of the extreme thickness of the lignite seams and the high value of the reclaimed 1 and. 
Experiments have been performed to test the feasibility of reclaiming arid and semi-arid stripped 1 ands without irrigation. Snow fences were erected on a semi-arid Wyoming plot to test their effectiveness of retaining the moisture of winter storms. The idea was marginally successful; soil moisture increased only when the fences were placed on the leeward side of open, level areas (Commoner, et al. 1975). An experiment on arid land in Washington State collected natural precipitation in gullies between spoil piles. The slopes of the spoil piles were treated with various materials, including rubber, to enhance runoff. Results of the experiment are preliminary, but the first harvest yielded over 22 bushels per acre of cultivated gully with rubberized slopes; the overall yield was 5.2 bushels per acre due to the small portion of cultivated 1 and. No cost estimates of the procedure are available (Sauer 1978).

\section{Water Pollution Effects of Mining}

Coal mining can cause pollution of adjacent streams and ground water if the operations are not carefully controlled. Potential pollutants include suspended solids, sulfur compounds, oils, nitrates, and ammonia. Contamination of streams can be avoided by grading spoil piles and other disturbed areas so runoff is collected in ponds and allowed to evaporate or to be used for dust control or revegetation.

\section{Suspended Solids}

The most serious water pollution problem associated with coal mining is the increased suspended solid load of adjacent streams caused by runoff from disturbed 1 and. The amount of sediment which can emanate from a given mine depends on the extent of the disturbed 1 and, the frequency and intensity of rainfall, and the specific topography. Sedimentation in streams can interfere with the growth of aquatic flora and $f$ auna, and can impede flow which promotes flooding.

\section{Sulfur Compounds}

Sulfur compounds, especially pyrite and hydrogen sulfide, are of ten found in coal seams or in overburden. When sulfur compounds become exposed to air 
Decker, groundwater levels dropped over $20 \mathrm{ft}$ in two years in wells less than one mile from an active mine (NGPRP 1975). At a distance of one and one half miles, the drop in the water table was $10 \mathrm{ft}$ (Polzin 1974). A study done on a hypothetical mine near Gillette, Wyoming indicates that the extent of water table decline depends on specific aquifers and on the direction of groundwater flow. A well five miles west of the mine may experience a decline of over $100 \mathrm{ft}$ while a well one mile east may not be affected (Keefer \& Hadley 1976). The effects of groundwater decline are usually quite localized and farmers and ranchers with wells within a few miles of active mines could probably alleviate any problems by drilling their existing wells deeper. It is speculated that groundwater levels will recover after mining operations cease and the pits have been backfilled. A period of ten years has been suggested as the recovery time but no one knows for sure (BuRec 1977). Aquifers may suffer water quality problems after mining as water percolating through disturbed soil will tend to dissolve more minerals than that percolating through undisturbed soils.

\section{Surface Water Effects}

The flow in streams near mining operations can be either decreased or increased by the mining operations. Springs which feed streams could dry up as a result of pit dewatering activities. Sometimes, however, dewatering activities yield more water than can be used or stored and excess must be discharged to streams.

When surface mines intercept streambeds, the flow must be diverted around the mine. This change in the natural topography can cause erosion and sedimentation problems. When the coal seam thickness is 1 arge compared to the overburden, depressions will remain even after backfilling. The stream diversion must become permanent or the depression will form a lake. In general, this is undesirable due to groundwater quality problems. Some small ponds, however, may be beneficial for use as livestock watering holes or irrigation storage. Runoff which accumulates in the depressions does not present an infiltration problem due to the small amount of precipitation and the fact that infiltration rates through backfill are typically lower than through undisturbed soil. 
they can oxidize to sulfate which will form sulfuric acid when contacted with water. This is the origin of the notorious acid mine drainage which has destroyed hundreds of miles of streams in the eastern U.S. The problem is not as severe in the West because Western coal typically has much less sulfur than does Eastern coal.

$\underline{0 i 1 s}$

$0 i 1 s$, greases, and fuels from equipment maintenance can enter streams if preventive care is not taken. $0 i 1$ can also be a problem when the coal mine is located near oil or natural gas deposits.

Nitrates and Ammonia

Blasting of coal seams and overburden produces nitrate and amonia residues. If runoff patterns from blasting areas are not controlled to contain these wastes, they can pollute streams. Even with proper contaiment, some of these residues will likely be released to the atmosphere from which they could settle and pollute streams.

Hydrologic Effects of Strip Mining

Strip mining operations often interfere with groundwater aquifers and surface streams.

\section{Groundwater Effects}

Coal seams and overburden of ten contain locally important aquifers whose levels decline due to mining operations. To extract the coal, mine pits must be dewatered to the lowest level of the pit. Because the overburden is generally more permeable than the coal, it will usually yield more water. Some mines in the Northern Great Plains yield up to 100,000 gal/day (NGPRP 1975). Studies in the Powder River Basin indicated the average ground water yield during production was about $12 \mathrm{gal} /$ ton of coal extracted while a mine near Decker, Montana, yields less than 5 gal/ton (Hittman 1974).

The groundwater levels in wells surrounding strip mines are lowered due to the dewatering operation, but a contributing factor to aquifer lowering near surface mines may be the decreased infiltration rates of disturbed land. Near 
Alluvial Valleys. Alluvial valleys are valleys whose floors are formed of stream-deposited silt and gravel sediments. This alluvium is quite permeable and is typically saturated with ground water. Mining operations on alluvial valley floors present special groundwater quality problems. There is potential for both polluting ground water and plugging the aquifer. For these and other reasons, the Department of the Interior has effectively banned coal mining on alluvial valley floors, under authority of the Surface Mining Control and Reclamation Act of 1977 . This action has been rather controversial because there is widespread disagreement among experts over the definition and identification of alluvial valley floors.

While the total amount of coal lying below alluvial valley floors may be small compared to the total amount of Western coal, the affected coal represents a significant proportion of the coal under Federal lease. There has been some recent consideration of exchanging affected parcels for others not covered by the new regulations. The details of the exchange program are not yet formulated. Because the affected coal fields are only in the western United States, western coal operators lost a competitive advantage over their eastern counterparts.

Curiously, the alluvial valley floor regulations apply only to coal mining and not to other activities such as quarrying which can be just as environmentally damaging. It is unclear why such a broad move by the Department of the Interior was required. They al ready had the power, under authority of the Federal Land Policy and Management Act of 1976, to protect ground water on a case-specific bas is by designating an area "unique."

\section{COAL TRANSPORTATION}

Of the various means of transporting the energy of coal, only the coal slurry pipeline option has significant water effects. High voltage transmission lines, railroads, and gas pipelines require certain amounts of water for construction, but it is not likely that cost or availability of water would be a limiting constraint. During operation these transportation modes also 
require some service and domestic water at substations, switchyards, or pumping stations, but these demands are negligibly small.

\section{Water Effects of Coal Slurry Pipelines}

Coal slurry pipelines offer a potential for economic coal transportation with minimal environmental effects. This potential, however, has been exploited only to a limited extent. The first coal slurry pipeline in the U.S. was the Consolidated coal line in Ohio which began operation in 1957 and shut down in 1963. Its presence forced the railroads to adjust their operating procedures and tariffs to remain competitive. The Black Mesa pipeline in Arizona and Nevada began operations in 1970 and is currently the only operating slurry line in the country. The ETSI line from Wyoming to Lousiana is nearing its construction phase. Six other coal slurry pipelines are now in planning stages (Figure 3 ).

Coal slurry pipelines use water for process and for transport (Figure 4). At the upstream terminal, water is required for crushing and cleaning, but effluent from these operations is typically recycled after settling so consumption is sma11. The major consumption of water occurs in the transport of the coal. Fine particles of coal are suspended by turbulence as the slurry flows through the pipe. This water is not consumed by the process and would typically be used for power plant cooling after being separated from the coal with centrifuges or chemical precipitation. However, with respect to the coal-producing region, water used to transport coal long distances must be considered consumed, as the costs of installing and operating a return pipeline would make the system uncompetitive.

\section{Water Quantity}

Proposed coal slurry pipeline designs call for a water to coal ratio of 1:1 by weight. Operational experience, and analytical studies indicate that this is near optimal (USGS 1977), considering the tradeoff between capital cost and operational cost. Slurries with less water may be pumped through smaller pipes reducing capital costs. However, as water content of a slurry decreases, the viscosity increases and energy costs of pumping increase. 


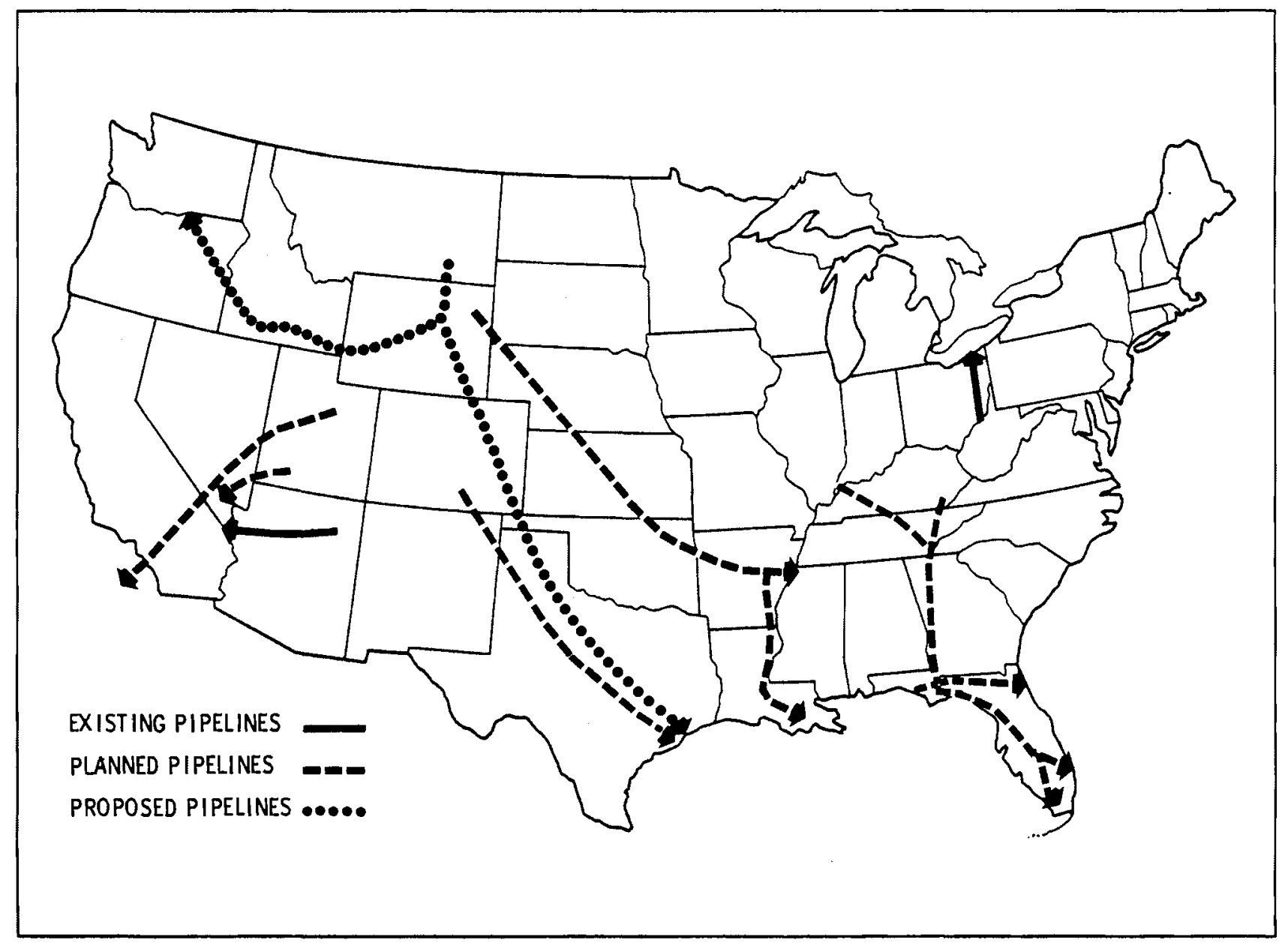

FIGURE 3. Existing and Planned Coal Slurry Pipelines

Likewise, slurries with more than $50 \%$ water would use less energy, but would require 1 arger pipes. The Consolidated coal line in Ohio was designed for $50 \%$ water. It was soon discovered that a $60 \%$ coal and $40 \%$ water mix was technically feasible (NGPRP 1974).

\section{Economic Considerations}

Although railroads disagree, the consensus among those involved with coal transportation seems to be that coal slurry pipelines are an economically competitive mode of transportation over long distances from coal fields which are remote from major waterways (barge hauling is also quite inexpensive, but obviously is practical only on large rivers or lakes). The cost of water does 


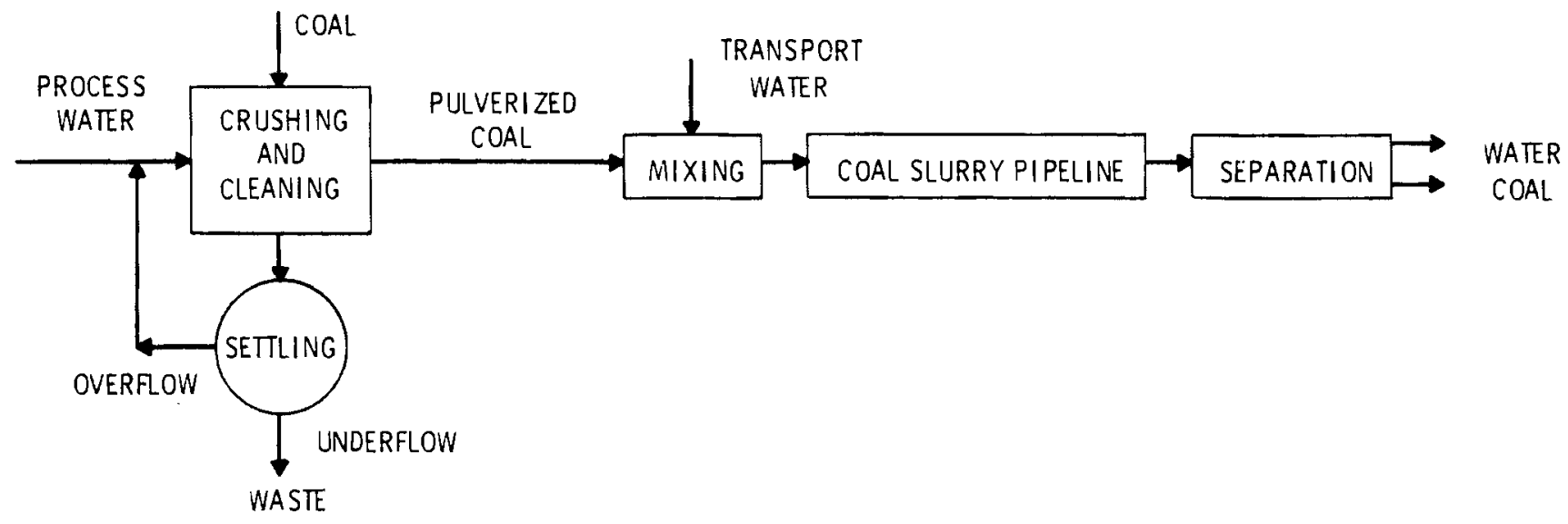

FIGURE 4. Water Systems of a Coal Slurry Pipeline

not greatly affect the operation of a pipeline; in order to rationalize a $10 \%$ savings in water consumption over that of the technically optimal design, it has been est imated that the cost of water would have to be $\$ 1000$ or more per acre-ft. Even at this price, the cost of water would represent at most $20 \%$ of the total annual cost of the pipeline and would probably be less than $10 \%$ (USGS 1977).

The $B l$ ack Mesa 1 ine has been paying on 1 y $\$ 6.67$ per acre-ft of shallow ground water under the terms of a ten-year lease (NGPRP 1974). The proposed ETSI line will be economical even though the water cost will be substantially greater than that at $\mathrm{Bl}$ ack Mesa. The cost of water from several potential sources has been estimated by ETSI. The least expensive option is to obtain water from a deep (several thousand feet) aquifer known as the Madison Formation, which extends throughout much of the coal-producing region of wyoming. The pipeline company expects their unit cost to be around $\$ 130$ per acre-ft. The least expensive surface water source would involve a diversion from the 0 ahe Reservoir several hundred miles away in South Dakota and is estimated to cost $\$ 1000$ per acre-ft. Recycling the water from the downstream terminal to Wyoming would require a parallel pipeline and would cost around $\$ 3,500$ per acre-ft (Odasz 1978). 


\section{Political Problems}

To farmers, ranchers, and environmentalists (as well as railroad people), coal slurry pipelines have the notoriety of a hungry bear on one's doorstep. The mood of the region is that the water resources of the area should be used for irrigation or livestock watering, and proposals involving export of water border on sacrilege. Because this feeling is so pervasive, pipeline planners should expect strong opposition to each proposal. Recent legislation in Montana reflects the attitude of agriculturalists and environmentalists. No water rights greater than 15 cfs may be transferred from agricultural uses to energy development, and no water from Montana may be used for coal slurry pipelines as this is legislatively defined to be nonbeneficial. While opinions on the benefits of slurry pipelines differ, these laws reflect genuine apprehension by the existing Montana population.

The controversy over control of water rights is essentially a manifestation of the old controversy between state's rights and Federal authority. South Dakota requires all water right applications in excess of 10,000 acre-ft/ $\mathrm{rr}$. to be approved by the state legislature. The Wyoming legislature has passed a 1 aw that prohibits the export of any ground water from the state without the explicit approval of the state legislature. State's rights advocates contend that because water has traditionally been considered the property of the state (with the state issuing permits to use the public property) each state has the right to determine how and where its water is used. The state goverment is in a better position than the Federal government to determine what water uses accrue the greatest benefits to the state (University of Wyoming 1975). Advocates of Federal authority argue that state restrictions on water use are unconstitutional because they represent a barrier to interstate commerce. This position would seem to have the benefit of legal precedent as a U.S. district court has held as unconstitutional a Texas law which was similar to the Wyoming $1 \mathrm{aw}$. The Supreme Court has affinmed the district court ruling without written opinions (Trelease 1978).

Another potential political problem involves handling at downstream terminals. Much of the water used to pipe coal will be high in dissolved 
solids. These salts must eventually be handled as residuals. If the water is reused for cooling, the blowdown rate would have to be increased as well as the cost of treating the blowdown waste. Downstream states may be reluctant to allow the flow of water high in dissolved solids into their jurisdictions.

\section{ELECTRICAL GENERATION}

The 1 argest users of water along the coal fuel cycle are coal-fired power plants. Electric power generation in general has historically accounted for the majority of all water withdrawn from American streams. In recent years, up to $80 \%$ of all industrial water withdrawn in the United States has been for use in power plants (Commoner, et al. 1975). Only a small portion of this water is consumed; most is used for cooling and is returned to streams with waste heat from the process. With the Federally mandated constraints on oncethrough cooling systems, the relative amount of water withdrawn by the electric power industry will decrease, but the amount consumed will increase. Uses of Water in Power Plants

In addition to cooling requirements, coal-fired power plants require water for emissions control, ash handling, boiler feed, cleaning, and domestic purposes (Figure 5 ).

Cooling

Coal-fired power plants typically convert between $30 \%$ and $40 \%$ of the energy value of the coal into useful electricity. The remaining $60 \%$ to $70 \%$ must be disposed of as waste heat. Some of this waste heat (approximately $15 \%$ ) is dissipated directly to the atmosphere through the stack, but most of it is retained in steam. Energy from boiler steam is converted to mechanical energy when high-pressure steam expands against the turbine blades. The condenser improves process efficiency by decreasing the steam pressure on the back side of the turbine. The energy lost by the boiler steam in the condenser is absorbed by the cooling water.

A variety of schemes have been developed to handle cooling water after it has absorbed waste heat in the condenser. The simplest and (until recently) 


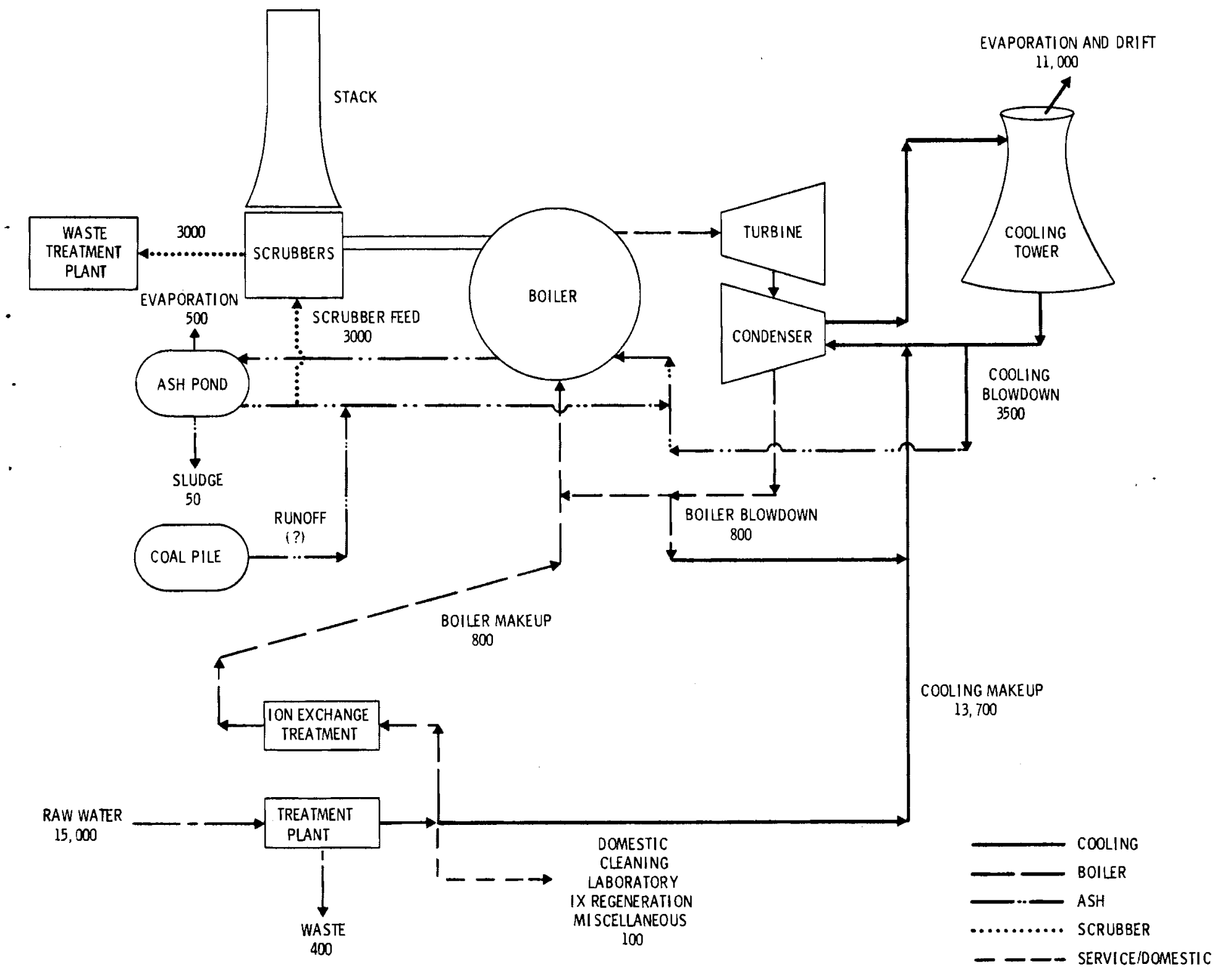

FIGURE 5. Water Systems of a Hypothetical 1000 Me Coal-Fired Power Plant (Annual Flows in acre-ft)

most popular system is once-through cooling. Other systems which have been used extensively are evaporative cooling towers, evaporative spray ponds, and cooling lakes. Systems which are beginning to receive consideration are dry cooling towers and wet/dry hybrid systems. 
Once-through cooling systems require a large continuous supply of water. The temperature is raised several degrees in the condenser, and the warmed water is immediately discharged. When power plants were few and $f$ ar between, the thermal effects on aquatic ecosystems were minimal and once-through cooling was acceptable. The rapid expansion of installed electrical capacity and more stringent enviromental criteria of recent years have aggravated and accentuated thermal effects such that they are now a major concern. Oncethrough cooling systems may still have applications with plants built along a sea coast or large inland lake, but EPA regulations under authority of the Federal Water Pollution Control Act Amendments of 1972 preclude them for most new power plants.

Evaporative cooling systems are the most popular alternative to oncethrough systems. These systems minimize the amount of cooling water discharged, and virtually eliminate thermal discharges to waterways. Energy absorbed in the condenser is rejected to the atmosphere by the evaporation of a small fraction of the cooling water. Most of the remaining water is recycled to the condenser. A small amount is blown down to control buildup of chemicals and salts.

A typical 1000 MWe power $\mathrm{plant}$, with a temperature rise of $20^{\circ} \mathrm{F}$ across the condenser, would evaporate $21 \mathrm{cfs}$ in a wet cooling tower. Blowdown would be about $6 \mathrm{cfs}$, and other losses would be less than $3 \mathrm{cfs}$. About $1050 \mathrm{cfs}$ would be circulating through the system (Commoner et al. 1975). The total cooling water withdrawal requirement for this typical plant would be less than 30 cfs. A comparable plant with once-through cooling may withdraw up to 1500 cfs. Essentially all of the cooling water of a once-through system is returned to the waterway, but nearly all the water withdrawn by an evaporative system is consumed or otherwise lost by the process.

There are three basic types of evaporative cooling systems: natural draft towers, mechanical draft towers, and spray ponds. Each consumes between 0.70 and $1.50 \mathrm{gal} / \mathrm{net} \mathrm{kWh}$ with mechanical towers toward the high end of the range and natural draft towers near the lower end (Hauser and 0leson 1970). Important factors that affect the water consumption rates of evaporative 
cooling systems include wet bulb temperature, relative humidity and condenser temperature rise. Wind speed and insolation al so affect consumption rates of spray ponds.

Natural draft cooling towers are hyberbolic in shape and typically several hundred feet high. Warm water is sprayed into the top of the tower and heat transfer by evaporation and conduction occurs between the water and air as the droplets fall. Air is warmed near the top and becomes more buoyant. The warm air rises and draws cool, dry air from below. Operating costs of natural draft cooling towers involve only the power required to pump the water. The major capital cost is for the structure.

Mechanical draft cooling towers are typically much smaller than natural draft systems of comparable capacity. Warm water drips down slats as air is forced by with fans. Operating costs for mechanical draft systems include the power cost of driving the fans as well as the pumps. The structural cost is less than with natural draft systems, but the capital cost of machinery is an added consideration.

Spray ponds transfer heat by spraying droplets into the air. Some heat is also transferred by conduction and evaporation off the pond surface, al though these contributions are minor. Operating costs involve only the power required to spray the water. Capital costs are mainly for 1 and and earthwork.

Cooling lakes transfer heat from the water surface to the atmosphere by conduction and radiation as well as by evaporation. Cooling lakes simulate the receiving body of a once-through system so the operating costs are quite low. This advantage is usually more than offset by the vast 1 and requirements. Power plants require between 1 and 2 acres of cooling lake per megawatt of installed capacity (Hendrickson 1978). A typical 1000 MWe power plant could therefore require a lake with a surface area of over three square miles.

Dry cooling systems and wet/dry hybrid systems are beginning to be considered for areas where water is extremely scarce. Basically, a dry cooling tower is a large forced draft heat exchanger, similar to an automobile 
radiator. Heat transfer is accomplished entirely by conduction so the heat transfer surface must be very 1 arge to achieve the required degree of cooling. Therefore, the capital costs are extremely high when compared with those of evaporative systems. Because dry cooling systems lose efficiency on hot days more coal must be burned to maintain plant capacity.

The selection of a cooling system for a coal-fired power plant is a sitespecific process. In general, cooling towers are the systems of choice in the eastern United States and near metropolitan areas where land costs are relatively high. In the West, land costs are typically rather low, and spray ponds or cooling lakes merit consideration. Meteorological conditions in the West often preclude the use of natural draft cooling towers, but mechanical draft towers perform well. Dry cooling systems are economical only when water is extremely scarce, as in the southwestern U.S. Various studies indicate that dry systems become economically competitive with wet cooling systems when water costs are in the range of $\$ 200$ (Hendrickson 1978) to $\$ 750$ per acre-ft (Knapp and Leistrizt 1978).

Water quality is seldom a limiting constraint on cooling systems. Almost any natural surface water can be made suitable for cooling purposes. Usually, the only chemicals that must be added are a biocide such as chlorine to control algae growth, and a sequestering agent or acid to inhibit scaling. Water quality does affect the operation of cooling systems. In general, waters with high levels of dissolved solids must be blown down at a high rate to control buildup of dissolved solids. Concentration factors of evaporative cooling systems (the ratio of makeup to blowdown water) range from about 3.0 to 15.0 and are typically around 6.0 .

The purpose of the trend away from once-through cooling systems is to protect waterways from the effects of thermal residuals. The heat assimu1 ation capacity of the atmosphere is much higher than that of streams, but there are still localized problems. The biggest problem associated with evapor ative cooling is fog formation. Under certain meteorological conditions, the moisture emitted from cooling towers can create a dense bank of fog. This can create hazards on nearby highways. Although it is 
speculated that the cooling towers affect the microclimate downwind, with especial impact on humidity and precipitation, studies into this possibility are inconclusive.

Another potential pollutant from cooling towers is salt dissolved in drift (droplets of liquid water that become entrained in the air moving through the tower and subsequently leave the tower with the air). The water usually evaporates quickly and the salt precipitates. Perhaps three millionths of an inch of salt may be deposited on land within half a kilometer of a power plant each month (BuRec 1977). There is potential for this salt to run off into a stream and thus pollute the waterway, but its effect on terrestrial vegetation is potentially more damaging. Modern cooling towers are designed to virtually eliminate drift and thus the salt deposition problem.

\section{Emission Control}

A major use of water in modern coal-fired power plants is for stack gas emission control. Major air pollutants which must be controlled include sulfur compounds and particulates. Before discharge, flue gases pass through scrubbers where a fine mist of water is entrained in the flue gas. Particles are absorbed by the droplets and agglomerated. Lime or limestone is of ten added to the scrubber water to precipitate the sulfur compounds.

The amount of water used by scrubbers is dependent upon many factors including the sulfur content of the coal and ambient air conditions. A 1000 MWe coal-fired power plant will require between 3000 and 8000 acre-ft of water per year for scrubber operation, but this is typically toward the low end of this range (BuRec 1977 and Bhutani 1975). Much of the coal from the western United States has low sulfur levels and, until recently, could be legally burned without flue gas desulfurization equipment, providing some other type of particulate controls such as electrostatic precipitators, were provided. Recently, however, EPA proposed new regulations concerning $\mathrm{SO}_{2}$ removal which will require virtually all coal-burning facilities to provide scrubbers. These regulations, however, are not yet finalized. 
Water quality is not an important factor with respect to scrubber influent. Effluents from scrubbers contain many potential water pollutants and must be treated before they are discharged.

\section{Ash Handling}

Large quantities of ash are produced when coal is burned in boilers. Some of this ash escapes with flue gases and is removed as particulates. Most of the ash falls to the bottom of the boiler and is then sluiced to holding ponds. A 1000 MWe power plant requires between 700 and $3000 \mathrm{acre}-\mathrm{ft} / \mathrm{yr}$ of water for ash handling (BuRec 1977). The biggest factors affecting this amount are the ash content of the coal and operating procedures. Some water is evaporated by the hot ash and some is removed with the ash sludge after settling, but most of the water can be recycled.

Water quality is not a constraint on ash sluicing water. If spent ash sluicing water is to be discharged, settling is usually sufficient treatment. The ash sludge must be handled as solid waste and is typically buried in a 1 andf $i 11$.

\section{Boiler Feed}

One use of water within a power plant for which influent water quality is an important factor is the boiler feed. Boiler water flows through tubes in the walls of boilers and absorbs energy released by the combustion of coal. The temperature of the boiler water is raised to around $1000^{\circ} \mathrm{F}$ at pressures of several thousand pounds per square inch. Under such extreme temperature and pressure conditions, impurities in the water promote scaling or corrosion of boiler tubes and turbine blades quickly. The biggest scaling problems are caused by divalent metal ions, notably calcium and magnesium. Treatment of boiler feed water typically entails ion-exchange softening and addition of sequestering chemicals. Boiler water must be blown down periodically to control the buildup of added chemicals. Blowdown rates are dependent on the quality of the make-up water and operating procedures, but are typically between 1 and 2 cfs (NGRRP 1974 and BuRec 1977). An annual requirement of 800 acre-ft for a 1000 Me power $p l a n t$ is a reasonable figure for estimation. 


\section{Cleaning}

Water is used to clean a myriad of surfaces around power plants. The most important surfaces are those of the boilers. Heat transfer efficiency is reduced when boiler surfaces become fouled, so they are cleaned periodically. Steam electric utilities clean their boilers an average of once every thirty months (Nichols 1974). High-pressure water jets are used to clean exposed boiler surfaces, but internal surfaces must be cleaned with chemicals. Waste waters from boiler cleaning operations contain high levels of heavy metals; for example, effluents from a single cleaning of a large power plant may contain over 4,200 pounds of heavy metals (Haller, et al. 1977). The source of most of the metal is the coal, but some may come from corrosion of the boiler itself. Steam electric power plants are a major contributor to the heavy metal load of the nation's waterways. Up to $50 \%$ of chromium, $21 \%$ of zinc, $14 \%$ of copper, $10 \%$ of iron, and $14 \%$ of all heavy metals discharged by U.S. industries are from power plant cleaning operations (Nichols 1974).

In addition to heavy metals, cleaning wastewater from boilers and elsewhere in the power plant may contain oils, detergents, organics, and suspended solids.

The quantity of water required for cleaning varies greatly from plant to plant and is dependent on operating procedures, impurities in the coal, and the age and size of the plant.

\section{Other Water Uses}

Other water uses in a power plant include laboratory uses and domestic uses. These demands are typically rather small. A 1000 MWe power plant may have a domestic and $1 \mathrm{ab}$ water requirement of 10 acre-ft/yr, but this is probably toward the high end of the range (Nichols 1974). Effluents are typically discharged to a municipal sanitary sewer system or an onsite treatment facility.

Power Plant Water Systems

Figure 5 shows potential relationships between the various water systems within a hypothetical power plant. Some of the systems receive their 
influents from the effluents of other systems. Waste streams of several systems are combined for treatment. It is likely that recycling and waste handling technologies will advance significantly in the next few decades resulting in decreased water withdrawal and waste water discharges.

\section{Recycling}

Because water quality is not an important parameter for many uses of water within a power plant, waste water can be used. Boiler blowdown is suitable for cooling water makeup and cooling blowdown is suitable for ash sluicing or flue gas scrubbing. Some power plants have successfully used secondary effluent from municipal sewage treatment plants as cooling water makeup, but additional treatment for removal of phosphate, ammonia, and dissolved solids is usually required.

\section{Waste Water}

The central treatment plant of a modern coal-fired power plant handles the waste streams from equipment cleaning, ion-exchange regeneration, scrubbers, boiler blowdown, and the laboratory. Typically, the treatment involves flocculation, clarification, and filtration. For equipment cleaning wastes containing oils or heavy metals, skimming and lime softening may precede the main treatment processes.

Other waste streams are handled separately. Runoff from coal storage piles is collected and usually used for ash sluicing. Waste water from the ash handling system is typically clarified and discharged or used for flue gas scrubbing. Chemical wastes from boiler tube cleaning operations may be shipped away for disposal in a hazardous waste 1 and fill, or may be discharged to a municipal sewage treatment plant, depending on local regulations and chemicals used. Damestic waste is usually discharged to an onsite or municipal sewage treatment plant.

The technology of waste water treatment is currently undergoing rapid expansion as EPA has set a goal of zero pollution discharges by 1985 . 


\section{Cogeneration}

There have been numerous proposals for utilizating waste heat from power plants rather than discharging it to waterways or the atmosphere. Cogeneration, as these processes are termed, would significantly reduce the water withdrawal requirements of a power $\mathrm{plant}$ by reducing or eliminating water lost by evaporative cooling. There are two basic schemes for using a power plant's waste heat. One would use low-quality steam directly after it passes through the turbine, eliminating the need for a condenser. The other would use warm water from the cooling loop of the condenser. Each of these schemes has several potential applications.

American industry uses vast amounts of low quality process steam. Traditionally, process steam has been generated onsite when needed, but it is recognized that substantial energy savings could be achieved if industry could use utility-generated steam after it has been used to produce electricity. This type of cogeneration has been demonstrated successfully for several decades, but its use in the United States is still quite rare. For such an arrangement to work, there must be a continuous demand for the waste steam by industries in close proximity to the power plant. When users are $f$ ar away, the heat lost in transmission and the capital cost of the system make cogeneration impractical.

Another application of waste steam is district heating. In the early decades of this century, space heating with steam from urban utilities was fairly common. Users were often charged a fee based on the amount of condensate discharged to sewers. As utilities increased boiler temperatures and pressures to increase efficiency, more elaborate water treatment systems were required to prevent scaling. The increased value of the treated water precluded discharging it to sewers, and capital costs precluded returning it from district heating networks to power plants. With increased energy costs, such a cogeneration system may once again become economical.

District heating systems employing warm water from the condenser may be more feasible than those using steam directly. Extensive treatment of cooling 
water is not required so recycling it to the plant would not be necessary. A study of potential uses for low-temperature waste heat from the Oak Ridge gaseous diffusion $\mathrm{plant}$ indicated that $140^{\circ} \mathrm{F}$ water could be delivered to Knoxville for space heating applications, 36 miles away, at a cost of $\$ 1.20$ per million Btu (Exxon 1978). The system would be cost effective because of its capital intensity; the costs of alternate energy systems would escalate at a faster rate. This analysis assumed that $100 \%$ of eligible users would hook up to the system. With only two-thirds participation, distribution costs would increase $50 \%$.

A major problem with cogeneration is the incongruities that exist in supply and demand of waste heat. A base-load power plant has a continuous supply of heat that must be rejected, whereas space heating load varies with the weather. Because of this, the utility must incur the capital expense of an alternate cooling system. This, combined with the low return-on-investment of selling warm water, is a disincentive for utilities to become involved with space heating cogeneration. This problem may be overcome in the future by development of seasonal thermal energy storage in aquifers. Warm water could be injected in the summer and withdrawn for use in the winter. The feasibility of such a system has not yet been proven but the Department of Energy is sponsoring research in this promising program.

Other applications of low-temperature waste heat which have potential are the enhancement of agriculture and aquaculture. The 0ak Ridge study indicated that the cost of delivering energy to greenhouses two miles from the $p l$ ant would be $\$ 3.00$ per million Btu while conventional greenhouse heat costs $\$ 4.60$ per million Btu (Exxon 1978). The study warned, however, that using over $0.05 \%$ of the 1440 MWt of waste heat could saturate the local market for vegetables and flowers.

Certain aquatic species grow faster in slightly warmed water. For example, shrimp have been found to grow $80 \%$ faster at $80^{\circ} \mathrm{F}$ than at $70^{\circ} \mathrm{F}$ (Nichols 1974). The optimal temperature for catfish production is $83^{\circ} \mathrm{F}$. The Oak Ridge study considered both shrimp farming and catfish farming as uses for lowtemperature waste heat. Both were found to be uneconomical (Exxon 1978). 
It is likely that there are many potential applications of cogeneration which have not yet been studied or even proposed. The feasibility of given applications at a certain power plant must be considered on a case by case basis.

\section{COAL CONVERSION}

There have been numerous schemes proposed to convert coal from its solid form to gaseous or liquid fuels. There are several advantages of converted coal as well as some disadvantages. Probably the most significant advantage would be replacement of imported petroleum with domestically produced synthetic fuel--a goal competing these days with apple pie and motherhood as allAmerican virtues. However, the electric power industry is interested in coal conversion for two other reasons. Coal conversion facilitates transportation of coal energy and eliminates particulate and sulfur dioxide emissions from combustion of coal. The main disadvantage of coal conversion is the current high cost of the technology. Of the two conversion products, the technology of gasification seems more advanced than that of liquefaction.

\section{Coal Gasification Plants}

Water is used for three main purposes within a coal gasification plant: cooling, process steam, and gas scrubbing, plus several minor purposes. Figure 6 shows the water systems in a typical coal gasification process.

\section{Cooling Water}

Cooling requirements are dependent on the overall efficiency of the conversion process; a less efficient process will reject more heat than a more efficient process. Commercial plants are expected to employ a mix of forced air dry cooling and evaporative cooling. In areas where water is readily available, perhaps $25 \%$ to $60 \%$ of the waste heat will be rejected by evaporation while in water-scarce areas up to $90 \%$ may be handled with dry cooling (Probstein and Gold 1978).

\section{Process Water}

Coal gasification is accomplished by increasing the hydrogen-to-carbon ratio of coal-based carbon compounds at high temperatures and (usually) high 


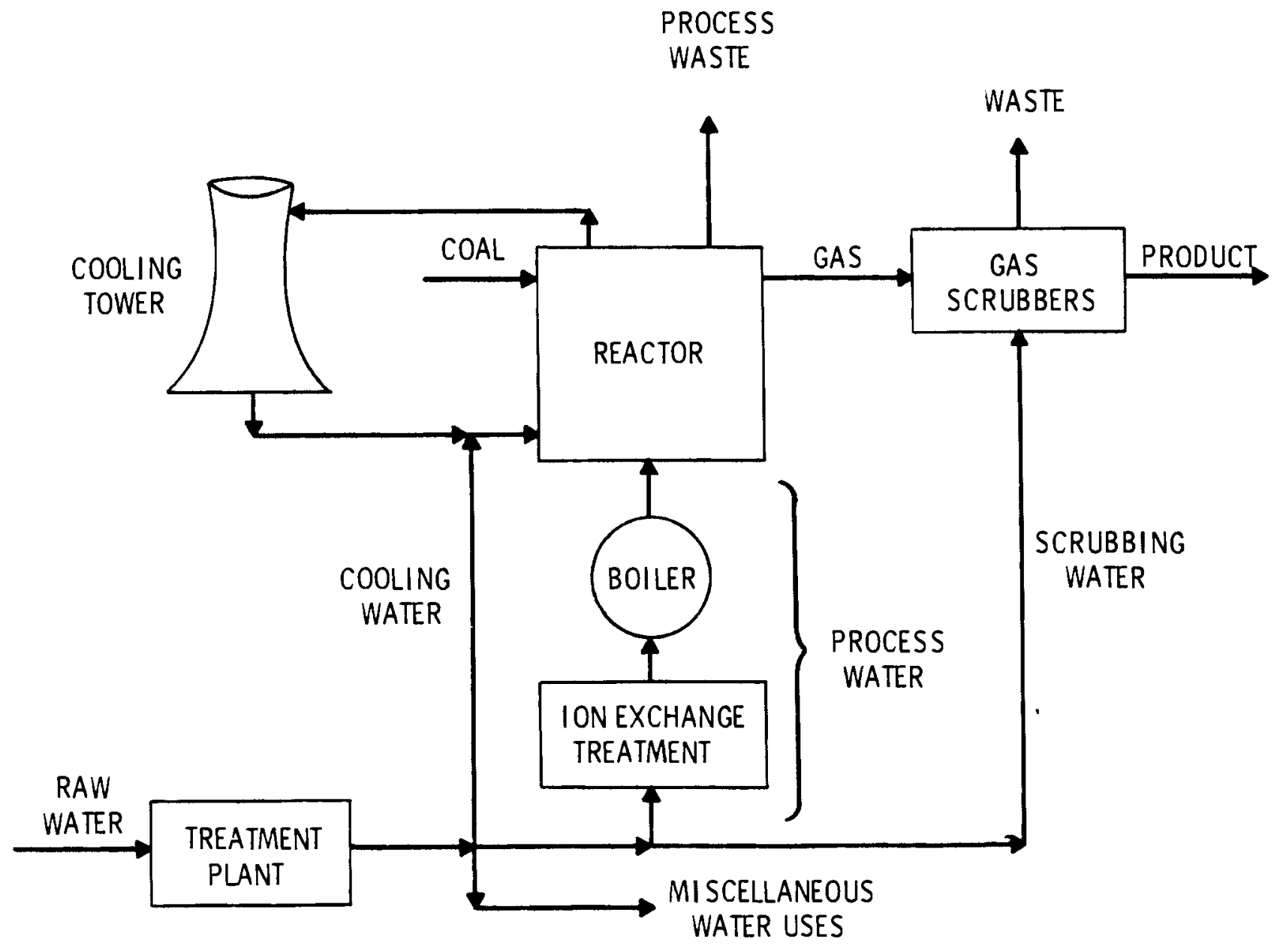

FIGURE 6. Water Systems of a Typical Coal Gasification Process

pressures in a gasification reactor. The source of heat and hydrogen in the reactor is steam. Stoichiometrically, a $250 \mathrm{million}$ standard cubic feet per day (scf/day) plant would require 3400 acre-ft/yr of water to provide the hydrogen required to convert the solid coal to gaseous methane (BuRec 1977). Actual process stream requirements will be somewhat more than this, as the chemical processes are not $100 \%$ efficient.

\section{Scrubbing Water}

Gas produced in reactors typically contains tars, oils, and phenols, and must be scrubbed to remove these. The water quantity required for this is expected to be small compared to other streams in the plant. It is anticipated that effluents from scrubbing operations will be treated and recycled. 


\section{Other Water Uses}

Miscell aneous uses of water in a coal gasification plant include cleaning, ash handling, and domestic use.

Water Quantity Requirements

Because the technology is in such an early stage of development, it is not known for certain how much water will be required for a production scale coal gasification plant. A review of the literature reveals a wide range of estimates of the quantity of water that would be consumed by a 250 million scf/day plant, the size most of ten suggested for commercial feasibility. Some estimates reported in the literature seem to be $10 \mathrm{w}$, such as $2,300 \mathrm{acre}-\mathrm{ft} / \mathrm{yr}$ by EPA (NGPRP 1974) while others seem high, such as 49,000 acre-ft/yr by the Office of Coal Research (Schemetz 1974). Other more likely estimates are 6,000 and 12,000 acre-ft/yr (BuRec 1977 and NGPRP 1974). Probably the most credible estimates are those made in conjunction with actual designs of prototype plants. These estimates cluster around 7,300 acre-ft/yr for proposed plants in the Four Corners area where water is quite scarce (Schemetz 1974 and NGPRP 1974). Probstein and Gold (1978) have estimated water requirements for vavious systems within coal gasification plants. For $250 \mathrm{scf} /$ day plants, the estimates range from 1,400 to 3,600 acre-ft/yr for cooling, 3,900 to 5,800 acre-ft/yr for process and 1,500 to 6,000 acre- $f t / y r$ for scrubbing of western coal.

\section{Water Quality Effects}

Coal gasification processes require rather high quality water, and extensive treatment of plant influent will typically be required. Waste streams from coal gasification processes are similar to those from coking plants and will require extensive treatment prior to discharge or reuse.

Influent to coal gasification plants will most likely be treated with alum, lime, and polyelectrolytes in a flocculation/clarification process : After settling, the water is of adequate quality for cooling and a 1 arge portion will be diverted for this purpose. The rest of the clarified water will be filtered through sand, anthracite, or multi-media filters. A portion 
of the filtered water will be diverted to the domestic/service stream and will be treated further with acid for pH adjustments, chlorine as a biocide, and possibly activated carbon for organic removal. The rest of the filtered water will be treated by ion-exchange processes for removal of divalent metallic ions, notably calcium and magnesium. This stream will become the process water and must be quite pure to prevent scaling and corrosion in the hightemperature reactors.

The effluent streams of coal gasification plants will be similar in quality to those from coking plants and may contain suspended solids, oils, grease, phenols, ammonia, and other nitrogen compounds. The technology for treating wastes of this nature has been and is continuing to be developed by the steel industry. Treatment plants may include several physical, chemical, and biological processes, including: settling, surface skimming, activated sludge, chemical flocculation, clarification, filtration, and ammonia stripping. A challenge for treatment plant designers will be to improve the existing technology so that effluents can be recycled within the gasification plant, thus reducing total water withdrawal requirements.

\section{In-Situ Coal Gasification}

Another proposed scheme to gasify coal is in-situ gasification. Typical in-situ gasification processes involve drilling sets of air (or oxygen) supply holes and gas extraction holes. The coal seam is ignited and gases formed by partial combustion are extracted from the gas product hole. The efficiency on a Btu basis is generally much less than that of other gasification schemes, but advantages include not having to mine coal, elimination of many byproducts, and for 1 ower process water requirements.

One potential problem with in-situ gasification could be groundwater pollution. A preliminary study by Lawrence Livermore Laboratory indicates that groundwater pollution may not be as severe as previously expected because the charred coal remaining in the seam acts as a filter (Science News 1978). Much more research is required on groundwater effects as well as on the general technology of in-situ coal gasification before the process can be commercialized. 


\section{Summary}

Coal gasification will require water for processing, cooling, and cleaning and will produce waste streams which must be treated before discharge or reuse. Estimates of the water required for commercial scale plants vary widely due to the early stage of technology development.

It must be kept in mind that the water effects of coal gasification extend beyond the gasification plant. Because the process is less than $100 \%$ energy efficient, choosing the gasification option requires more coal to be mined to deliver the same amount of energy to end users than with other coal options. This, of course, will aggravate the water effects of mining operations. Gasification could affect the other end of the coal fuel cycle as well. The water effects of electric power generation using gasified coal will depend on the mode of generation. If air-cooled gas turbines or combined cycle plants are used to produce electricity, much less water will be required than if conventional steam-electric plants are used.

\section{DOMESTIC WATER EFFECTS OF COAL DEVELOPMENT}

Large scale development of the coal resources of the western United States would be accompanied by 1 arge influxes of new residents. Associated with this migration are many socioeconomic as well as technical problems. Among these problems is the need for new or expanded domestic water and sanitary facilities. Providing these systems is a technical problem; not providing them creates socioeconomic problems.

\section{Domestic Water Requirements}

The incremental domestic water requirements of a given development will be site-specific and depend on the size of the existing community, the climate, and the size and type of development (e.g., coal mine, power plant, gasification plant, etc.). In general, if the existing community is 1 arge, many or most of the construction workers and operators will come from within the community. When the community near an energy development is small, as is typically the case in the West, most of the workers will have to relocate and 
will contribute to the increased demand for domestic water. Warm, dry regions tend to have greater domestic water demands than do cool, humid regions. The estimated numbers of employees and dependents for various typically sized developments are shown in Tables 2 and 3.

Rules-of-thumb have been developed for estimating the annual average daily domestic demand. One figure of ten used is $160 \mathrm{gal} /$ day per capita

TABLE 2. Peak Construction Employment of Various Coal Developments

\begin{tabular}{|c|c|c|c|c|}
\hline Development & Size & Direct (a) & Indirect (a) & $\begin{array}{c}\text { Total (b) } \\
\text { w/Dependents }\end{array}$ \\
\hline Mining & -- & 100 & 180 & 670 \\
\hline Power plant & $1000 \mathrm{MWe}$ & 1,500 & 2,700 & 10,080 \\
\hline SNG plant & $250 \times 10^{6} \mathrm{scf} / \mathrm{day}$ & 2,500 & 4,500 & 16,800 \\
\hline Slurry pipeline & -- & 1,500 & 2,700 & 10,080 \\
\hline
\end{tabular}

(a) BuRec 1977.

(b) Assumes an average of 1.4 dependents/worker. This is toward low end of 1.2 to 2.4 range mentioned by WPPSS 1977 .

TABLE 3. Operational Employment of Various Coal Developments

\begin{tabular}{|c|c|c|c|c|}
\hline Development & Size & Direct (a) & Indirect $(a)$ & $\begin{array}{c}\text { Total (b) } \\
\text { w/Dependents }\end{array}$ \\
\hline Mining & $1 \times 10^{6}$ tons $/ \mathrm{yr}$ & 200 & 560 & 1,820 \\
\hline Mining & $10 \times 10^{6}$ tons $/ y r$ & 1,200 & 3,360 & 10,940 \\
\hline Mining & $100 \times 10^{6}$ tons $/ y r$ & 8,000 & 22,400 & 72,960 \\
\hline Power plant & $1000 \mathrm{MWe}$ & 300 & 840 & 2,740 \\
\hline SNG plant & $250 \times 10^{6} \mathrm{scf} / \mathrm{day}$ & 640 & 1,790 & 5,830 \\
\hline Slurry pipeline & $\ldots$ & 75 & 210 & 680 \\
\hline
\end{tabular}

\footnotetext{
(a) Burec 1977.

(b) Assumes an average of 1.4 dependents/worker. This is toward low end of 1.2 to 2.4 range mentioned by WPPSS, 1977.
} 
(Linsley and Franzini 1972). It should be noted that there has been a steady upward trend in per capita water use, so this figure may have to be revised periodically.

Annual average demands, such as the one mentioned above, are fine for estimating the total amount of water demanded by a community during a year, but are not appropriate for sizing a water system. Instantaneous demands during the course of a year may be widely variable. The peak daily demand may be two times the average daily demand and the peak hourly demand on a given day may be two times the average hourly demand. Therefore, the peak hour of the peak day may have a domestic demand of four times that of the average hour of the average day. In addition to the peak demand, extra capacity must be provided for fire protection.

The amount of domestic water required to support an energy development is almost insignificant when compared to other water requirements of energy development. Because the greatest domestic demand is during the construction phase, water availability typically would not be a constraint as there would presumably be water rights reserved for the operational phase. The significance of domestic water effects of coal development lies in financial problems associated with construction or expansion of municipal water systems rather than problems of availability.

Economic Considerations

The cost of domestic water and sanitary systems is site-specific. Basically, there are five components to the system that must be planned, designed, built, and ultimately, paid for: raw water collection, water treatment, water distribution, sewage collection, and sewage treatment. The raw water collection system may be a surface diversion with an aqueduct or may be a series of wells. Water treatment processes may include chemical flocculation and clarification using alum, lime or polyelectrolytes followed by disinfection, although some high quality waters may only require filtration and disinfection. The water distribution system conveys the treated water to users, and the sewage collection system collects it after use. The final 
system is the sewage treatment plant, which typically employs some type of biological treatment process.

The most costly components of the overall system are usually the water distribution and sewage collection networks. The per-capita costs of these are very dependent on the population distribution of the comunity. When the population is spread out, the costs will be quite high, but when the community is clustered, costs may be significantly lower. The water distribution system typically consists of an elevated storage facility, large diameter pressure mains, and small diameter laterals. There are some options that planners may consider on the sewage collection system. The most common sewage collection system consists of gravity sewers, but when the population is spread out, or when the terrain is variable, pressure sewers may be preferable. Capital costs per unit length of a pressure system are usually lower than those of a gravity system because pipe diameters can be much smaller and the pipe may foll ow the grade of the terrain rather than the hydraulic grade line. However, intricate valving and pumps must be provided at each source of sewage on a pressure system. Another sewage option is onsite treatment. This eliminates the need for a collection system and a centralized sewage treatment plant. Each household, however, must have a septic tank and soil-absorption field. In recent years, these low-technology treatment systems have experienced some disfavor among environmental engineers, mainly because of traditionally poor designs and proliferation in areas where the population is too dense for their proper operation. With careful design and proper maintenance, soil-absorption systems are still the best systems in many circumstances.

Small communities that are undergoing rapid expansion of ten lack the resources or the tax base required to float the bonds which are needed to undertake a water or sewage project. They are of ten reluctant to provide adequate facilities during construction phases of energy developments because after the project is built, many of the newcomers will move away, thus eroding the tax base. Various solutions have been suggested for the monetary problems. Some feel that the energy developers should internalize these 
community costs, i.e., they should pay the cost of providing adequate services for the people they lure into the community. Other people feel the Federal goverment should play a role in providing these services. The rationale is that the benefits of coal development will be distributed to the nation as a whole and therefore the costs should be likewise borne. Another idea is to use money from state severence taxes to provide community services. So far, no clear cut solution has been agreed upon, but with the expected energy boom in the West solutions must be found soon.

\section{SUMMARY}

Unit water requirement for various elements of a coal-based electrical energy supply system are shown in Table 4 . The ranges shown reflect differences reported in the available literature. The size of the range reflects the uncertainty inherent with the particular technology. For

TABLE 4. Water Requirements for Various Elements of a Coal-Based Electrical Energy Supply System

Element

Mine Dust Control

Mine Reclamation

Coal Washing

Slurry Pipelines

Steam Power Plant Cooling

Steam Power $P l$ ant Boiler Feed

Steam Power Plant Scrubbers

Steam Power Plant Total

Gasification Cooling

Gasification Process

Gasification Scrubbers

Combined Cycle Plant Cooling

Combined Cycle Plant Process

Combined Cycle Plant Total
Reasonable Range

\begin{tabular}{|c|c|c|}
\hline Low & High & Units \\
\hline 8 & 20 & gallons per ton of coal \\
\hline 0.5 & 2.0 & acre-ft per acre \\
\hline 5 & 15 & gallons per ton of coal \\
\hline 220 & 260 & gallons per ton of coal \\
\hline 10 & 12 & acre-ft per MWe-yr \\
\hline 0.6 & 1.0 & acre-ft per MWe-yr \\
\hline 2 & 5 & acre-ft per MWe-yr \\
\hline 12 & 18 & acre-ft per MWe-yr \\
\hline 15 & 40 & acre-ft per $10^{12}$ Btu \\
\hline 40 & 60 & acre-ft per $10^{12} \mathrm{Btu}$ \\
\hline 15 & 50 & acre-ft per $10^{12}$ Btu \\
\hline 8 & 12 & acre-ft per MWe-yr \\
\hline 5 & 10 & acre-ft per MWe-yr \\
\hline 10 & 20 & acre-ft per MWe-yr \\
\hline
\end{tabular}


example, cooling requirements for steam power plants are quite well documented, but gasification requirements are quite uncertain due to 1 imited experience. 


\section{WATER REQUIREMENTS OF A 10 GWe COAL-BASED ELECTRIC ENERGY SUPPLY SYSTEM}

Est imated water requirements for operation of various 10 GWe energy delivery systems using coal as the primary energy source are shown in Table 5. Table 6 lists the major assumptions that were used to calculate the water requirements. The data presented here were gleaned from various published sources. It should be noted that the available literature reports quite a range of water requirements for each step along the coal fuel cycle. The actual amount of water required for a future 10 GWe development will be site-specific and dependent on future technology.

\section{SCENARIOS}

Each energy delivery system configuration of Table 5 provides an average of 9 GWe of electrical energy to a load center approximately 1000 miles from the coal mine. It is assumed that the power is produced by base-load plants with load factors of $70 \%$. The system capacity factor of the nominal 10 GWe system is $90 \%$.

Mine Mouth Steam Generation with AC Transmission Lines

Electricity is generated at the mine mouth with $35 \%$ thermal efficiency. The power is transported to the load center on $765 \mathrm{kV}$ alternating current transmission lines with $95 \%$ thermal efficiency. Twelve steam generation units are required with capacities of 1128 Mwe each.

Mine Mouth Steam Generation with DC Transmission Lines

Electricity is generated at the mine mouth with $35 \%$ thermal efficiency. The power is transported to the load center on $\pm 600 \mathrm{kV}$ direct current transmission lines with $92 \%$ thermal efficiency. Twelve steam generating units are required with capacities of 1165 MWe each. Mine Mouth Gasification and Generation

Coal is converted to gas with $80 \%$ thermal efficiency and electricity is produced from the gas in a combined cycle plant with $41 \%$ thermal efficiency. The power is transported to the load center on $600 \mathrm{kV}$ direct current 


\section{TABLE 5. Estimated Water Requirements for Various 10 GWe Systems}

\begin{tabular}{|c|c|c|c|c|c|c|c|c|c|}
\hline \multirow[b]{2}{*}{ Generation Scheme } & \multirow{2}{*}{$\begin{array}{c}\text { Transport at i on } \\
\text { Model }\end{array}$} & \multirow{2}{*}{ Mining } & \multirow{2}{*}{ Transportation } & \multirow[b]{2}{*}{ Processing } & \multirow[b]{2}{*}{ Generation } & \multirow[b]{2}{*}{ Domestic } & \multicolumn{2}{|c|}{ Totals } & \multirow[b]{2}{*}{ Total } \\
\hline & & & & & & & Mine Area & Load Center & \\
\hline $\begin{array}{l}\text { Mine Mouth St eam } \\
\text { Generat i on }\end{array}$ & $\begin{array}{l}\text { AC Transmission } \\
\text { Lines }\end{array}$ & $3,000 / \mathrm{EAC}$ & zero & zero & 135,000 & 12,000 & & & \\
\hline $\begin{array}{l}\text { Mine Mouth Steam } \\
\text { Generation }\end{array}$ & $\begin{array}{l}\text { DC Transmission } \\
\text { Lines }\end{array}$ & 3,300 & zero & zero & 135,000 & 12,000 & 150,300 & zero & 150,300 \\
\hline $\begin{array}{l}\text { Mine Mouth Gasification } \\
\text { and Generation }\end{array}$ & $\begin{array}{l}\text { DC Transmission } \\
\text { Lines }\end{array}$ & 3,300 & zero & 66,000 & 142,000 & 24,000 & 235,300 & zero & 235,300 \\
\hline $\begin{array}{l}\text { Mine Mouth Gasification } \\
\text { Load Center Genera- } \\
\text { ti on }\end{array}$ & Gas Pipeline & 3,200 & zero & 66,000 & 142,000 & 24,000 & 81,200 & 154,000 & 235,200 \\
\hline $\begin{array}{l}\text { Load Center Steam } \\
\text { Generation }\end{array}$ & Unit Trains & 3,100 & zero & zero & 135,000 & 12,000 & 9,100 & 141,000 & 150,100 \\
\hline $\begin{array}{l}\text { Load Center Steam } \\
\text { Generation }\end{array}$ & Slurry Pipeline & 3,600 & 37,000 & zero & 135,000 & 12,000 & 46,600 & $122,500^{(a)}$ & 169,100 \\
\hline
\end{tabular}

(a) Reflects $50 \%$ utilization of slurry water. 
TABLE 6. Assumptions for Water Requirement Calculations

Heat Value of Coal: $9100 \mathrm{Btu} / \mathrm{lb}$

Coal Density: $80 \mathrm{lb} / \mathrm{ft}^{3}$

Coal Seam Thickness: $20 \mathrm{ft}$

Mining Efficiency: $80 \%$

Dust Control Requirements: $12 \mathrm{gal} /$ ton of coal

Reclamation Requirements: 1 acre- $\mathrm{ft} / \mathrm{acre}$

AC Transmission Efficiency: $95 \%$

DC Transmission Efficiency: $92 \%$

Gas Pipeline Efficiency: 94\%

Slurry Water Ratio by Weight: $50 \%$

Heat Loss Due to Moisture in Slurry: $20 \%$

Railroad Coal Losses: 2\%

Steam Electric Heat Rate: $9700 \mathrm{Btu} / \mathrm{kWh}$

Steam Plant Requirements: $15 \mathrm{acre-ft/MWe-yr}$

Gasifier Efficiency: $80 \%$

Gas Electric Heat Rate: $8400 \mathrm{Btu} / \mathrm{kWh}$

Gasifier Requirements: 100 acre-ft/10 12 Btu

Combined Cycle Requirements: 1.8 acre- $\mathrm{ft} / \mathrm{GWh}$

Domestic Requirements: 160 gal/day/capita

transmission lines with $92 \%$ thermal efficiency. Twelve combined cycle plants are required with capacities of 1165 MWe each.

Mine Mouth Gasification with Load Center Generation

Coal is converted to gas with $80 \%$ thermal efficiency and is piped to the load center with $94 \%$ thermal efficiency. Electricity is produced from the gas in a combined cycle plant with $41 \%$ thermal efficiency. Twelve combined cycle plants are required with capacities of 1071 MWe each.

Load Center Steam Generation with Unit Trains

Coal is transported to the load center by unit trains and electricity is produced by steam generation with $35 \%$ thermal efficiency. Twelve steam generating units are required with capacities of 1071 MWe each. 
Load Center Steam Generation with Slurry Pipeline

Coal is transported to the load center by slurry pipeline and electricity is produced by steam generation with 35\% thermal efficiency. Twelve steam generating units are required with capacities of 1071 Me each.

\section{SUMMARY}

Estimates of total water requirements for a coal-based electrical generating system with an average output of 9 GNe range from 150,100 acre-ft/yr for the unit train transportation option to 235,300 acre-ft/yr for the mine mouth gasification and generation scenario. The water requirement differences in mining reflect the varying quantities of coal required for the options. Coal slurry pipelines are the only transportation scheme that requires water, but part of the slurry water can be recovered and used in the steam generating plant. Gasification is the only coal processing step that requires significant quantities of water. The major water use in each scenario is electrical generation. Domestic water use is small.

Mine areas in the semi-arid west may experience critical water shortages. For this reason, it is beneficial to minimize the water requirements at the mine area. The scenario with the lowest water requirement at the mine area is the unit train option. The only water requirements are for mining and domestic use. Slurry pipelines also have relatively low mine area water requirements. All the other options have relatively high mine area water requirements.

It must be emphasized that this water analysis represents only a part of the total problem of coal development; a rational energy development decision requires a careful analysis of the trade-offs between economic, social, and environmental considerations. For example, the unit train option requires the least water but entails other problems such as noise and traffic tie-ups. On the other hand, the gasification scenarios require considerably more water than all the other alternatives but may also provide added benefits such as 
reduced air pollution or economical transportation. Among the myriad of factors, however, the availability of water is certain to be a major consideration when planning the development of a western coal resource. 


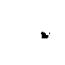




\section{REFERENCES}

Bhutani, J. et al. 1975. An Analys is of Constraints on Increased Coal Production. Mitre Corporation, McLean, Virginia.

Census of Agriculture. 1974. Volume III part 9, "Irrigation and Drainage of Farms." U.S. Department of Commerce, Bureau of the Census, 1978.

Cormoner, G. et al. Ed. 1975. Energy and Human Welfare - The Social Cost of Power Production.

Davis, G. H. and Kilpatrick, F. A. 1979. Water Supply as a Limiting Factor in Energy Development with Special Reference to the Colorado River Basin. Presented at the Conference on Western Water Issues, May 17-18, 1979 at Pas adena, California.

Exxon Nuclear Corp. 1978. Oak Ridge Gaseous Diffusion Plant Reject Heat Study Final Report. Richland, Washington.

Gold, H., et al. 1977. Water Requirements for Steam Electric Power Generation and Synthetic Fuel Plants in the Western United States. Water Purification Associates, Cambridge, Mass achusetts.

Goslin, V. 1975. Water Management in the Electric Power Industry. Center for Research in Water Resources, University of Texas, Austin, Texas.

Haller, W. A. 1977. "Duke Power Company Ash Basin Equivalency Demonstration for Metal Cleaning Wastes." Proceedings of the American Power Conference 1977 .

Hauser, L. G. and K. A. Oleson. 1970. "Comparison of Evaporation Losses in Condenser Systems." Proceedings of the American Power Conference - 1970.

Hendrickson, P. L. 1978. An Overview of Issues Affecting the Demand for Dry and Wet/Dry Cooling for Thermal Power Plants, Battelle Memorial Institute, 1978.

Hittman Associates. 1974. Environmental Impacts, Efficiency, and Cost of Energy Supply and End Use. Columbia, Maryland.

Keefer, W. R. and R. F. Hadley. 1976. Land and Resource Information and Some Potential Environmental Effects of Surface Mining of Coal in the Gillette Area, Wyoming. U. S. Geological Survey.

Knapp, J. W. and L. F. Leistritz. June 1978. "Resource Demands for Energy Development of the Yellowstone River Basin." Water Resources Bulletin. Volume 14, Number 3.

Linsley, R. K. and J. B. Franzini. 1972. Water Resources Engineering. McGraw-Hill, New York, New York. 
Northern Great Plains Resource Program. February 1974. National and Regional Energy Considerations Work Group Report. NGPRP, Denver, Colorado.

Northern Great Plains Resources Program. 1975. Effects of Coal Development in the Northern Great Plains. NGPRP, Denver, Colorado.

Nichols, C. R. 1974. Development Document for Effluent Limitations Guidelines and New Source Performance Standards for the Steam Electric Power Generating Point Source Category. U. S. Environmental Protection Agency, Washington DC.

Odasz, F. 1978. "Transportation: Pipeline Prespective." Presented to the Conference on Western Coal: Problems, Progress, and Promises, September $10-15,1978$, Keystone, Colorado.

Packer, P. E. 1974. Rehabilitation Potentials and Limitations of SurfaceMined Land in the Northern Great Plains. U. S. Forest Service, Washington DC.

Palmer, R. N., et al. 1977. Comparative Assessment of Water Use and Environmental Implications of Coal Slurry Pipelines. U. S. Geological Survey, Washington DC.

Polzin, P. E. 1974. Water Use and Coal Development in Eastern Montana: Water Availability, Water Demands and Economic Impacts. Montana State University, Bozeman, Montana.

Probstein, R. F. and H. Gold. 1978. Water in Synthetic Fuel Production. The MIT Press, Cambridge, Mass achusetts.

Rudolph, K. H. 1977. "A Time of Decision." Proceedings of the American Power Conference - 1977 .

Sauer, R. H. 1978. Precipitation Harvesting and Restoration on Strip Mine Spoils. Presented to the Internation Conference of Energy and Ecosystems, June 12 - 16, 1978, Grand Forks, North Dakota.

Schemetz, E., et al. 1974. "Water Requi rements for a Synthetic Fuels Industry Based on Coa 1." Proceedings of the Workshop on Research Needs Related to Water for Energy. Illinois University.

Science News. JuTy 8, 1978. Volume 114, No. 2.

Trelease, Frank J. Federal-State Problems in Packaging Water Rights. Presented at the Water Acquisition for Mineral Development Institute, March 16 and 17, 1978, Tucson, Arisona.

Uda11, S. L. 1963. The Quiet Crisis. Holt, Rinehart, and Winston, New York, New York. 
University of Wyoming. 1975. "It's Our Water!--Can Wyoming Constitutionally Prohibit the Exportation of State Water?" University of Wyoming Land and Water Law Review, Volume X, Number 1.

Water for Energy - Missouri River Reservoir Final Environmental Impact Statement. U.S. Bureau of Reclamation - 1977.

Water Policies for the Future. National Water Comission - 1973.

Water Quality Subgroup Report. Northern Great Plains Resources Program 1974.

Western States Water Requirements for Energy Development to 1990. Western States Water Council-1974.

Washington Public Power Supply System. 1977. Comparative Study of Coal and Nuclear Generating Options for the Pacific Northwest. Richland, Washington.

Wiel, S. C. 1908. Water Rights in Western States. University of Wyoming, Bancroft-Whi tney Co., Wyoming. 

(

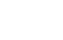


No. of

Copies

OFFSITE

A. A. Churm

DOE Patent Division

9800 S. Cass Avenue

Argonne, IL 60439

C. C. Diemond

4840 S.W. Fairhaven Lane

Portland, OR 97221

27 DOE Technical Information Center

T. F. Garrity

Division, Electric Energy Systems

U.S. Department of Energy

Washington, DC 20545

J. Hertog

Burlington Northern

176 East Fifth Street

St. Pau 1, MN 55101

W. R. Keefer

U.S. Geological Survey

Denver Federa 1 Center

Denver, CO 80225

J. Phinney

Conoco Coal Development Co.

Library, OH 15129

A. P. Sikri

Division, Fossil Fuel Extraction

U.S. Department of Energy

Washington, DC 20545
No. of

Copies

R. Swa in

Water and Land Power Resources

Service

Bldg. 56

Denver Federal Center

Denver, CO 80225

P. R. Weiber

Division, Fossil Fuel Extraction

U.S. Department of Energy

Washington, DC 20545

ONSITE

DOE - Richland Operations

H. E. Ransom

42 Pacific Northwest Laboratory

S. D. Akiyama

M. Clement

H. K. Elder

J. L. Eisenhauer

J. P. Haskins

P. L. Hendrickson

J. C. King (10)

R. C. Liikala

J. W. Litchfield

P. J. McGoey

T. E. Nugent

E. A. Rogers (10)

C. W. Roll and

R. L. Richardson

R. H. Sauer

G. E. Stegen

L. D. Williams

Technical Information Files (5)

Publishing Coordination $\mathrm{RO}(2)$ 
